\title{
Characteristics of shallow thermally driven flow in the complex topography of the south-eastern Adriatic
}

\author{
M. T. Prtenjak ${ }^{1}$, I. Tomažić ${ }^{2}$, I. Kavčič ${ }^{1}$, and S. Đivanović ${ }^{3}$ \\ ${ }^{1}$ Department of Geophysics, Faculty of Science, University of Zagreb, Zagreb, Croatia \\ ${ }^{2}$ Satellite Oceanography Laboratory, Ruđer Bošković Institute, Zagreb, Croatia \\ ${ }^{3}$ Department of Physics, Faculty of Science, University of Split, Split, Croatia
}

Received: 9 April 2010 - Revised: 7 July 2010 - Accepted: 12 July 2010 - Published: 20 October 2010

\begin{abstract}
Characteristics of thermally induced flow, namely the sea breeze, are investigated along the south-eastern Adriatic. The chosen period 24-25 April 2006 favoured sea breeze development and simultaneously allowed a comparison of the large-scale wind influence (north-westerly wind versus south-easterly wind) and the complex terrain on the local circulations. Particular attention is paid to the smallscale formation of the wind field, convergence zones (CZs), channelling flows and small scale eddies, especially in the vicinity of two airports in the central part of south-eastern Adriatic. The results are based on wind measurements (from meteorological surface stations, radiosoundings, satellite data and sodar data) and further supplemented by model data at fine grid spacing.

This study shows the formation of numerous irregular daytime and nighttime CZs, which occurred along the coastline in the lee of mountains and over the larger, elongated islands. The results show that the above mentioned airports are surrounded by daytime $\mathrm{CZ}$ formations within the lowermost $1000 \mathrm{~m}$ and associated updrafts of $1 \mathrm{~m} \mathrm{~s}^{-1}$, especially if CZs are maintained by the north-westerly largescale winds. Whereas the daytime $\mathrm{CZ}$ was generated due to merged sea breezes, the weaker and shallower nighttime CZs were formed by wind convergence of the seaward breezes, and significantly modified by the large-scale flow of the topography (e.g., accelerated flow in the sea channels and substantial swirled flows around the islands).

The passes between the coastal mountain peaks changed the inflow penetration, provoking the increase in wind speed of the channelled flow. The strongest sea breeze channelling
\end{abstract}

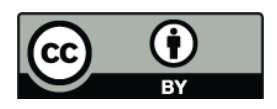

Correspondence to: $\mathrm{M}$. T. Prtenjak (telisman@gfz.hr) was observed above the valley of the Neretva River, where the onshore flow reached $40 \mathrm{~km}$ inland with a strength of $8 \mathrm{~m} \mathrm{~s}^{-1}$, and the highly asymmetric offshore part was confined within the sea channel.

Keywords. Meteorology and atmospheric dynamics (Mesoscale meteorology; Ocean-atmosphere interactions; Turbulence)

\section{Introduction}

The complex topography of the Adriatic coast (Fig. 1) is often influenced by a variety of thermally and dynamically driven wind systems. One of these systems is the sea/land breeze (SLB), a well-known worldwide mesoscale phenomenon (e.g., Simpson, 1994; Miller et al., 2003). This phenomenon is commonly observed at the Adriatic coast (e.g., Orlić et al., 1988; Prtenjak and Grisogono, 2007) due to temperature and consequent pressure differences between land and sea. Here the SLB develops, usually during the summer, when the high-pressure system of the Azores extends to south-eastern Europe and the whole Adriatic lies within the region of weak pressure gradients (Pandžić and Likso, 2005). Apart from the SLB development, in the same synoptic conditions the Etesian winds blow over the Adriatic and thermally induced slope winds and/or mountain-valley winds occur as well above the mountainous coast. Whereas the eastern Adriatic coast is highly complex, with numerous islands, islets and cliffs and with the mountainous coastline, the western Adriatic coast is low and mostly sandy, with a much more regular shoreline. Consequently, there are significant differences in the summer wind regime between the eastern and western Adriatic coasts, as well as between the

Published by Copernicus Publications on behalf of the European Geosciences Union. 


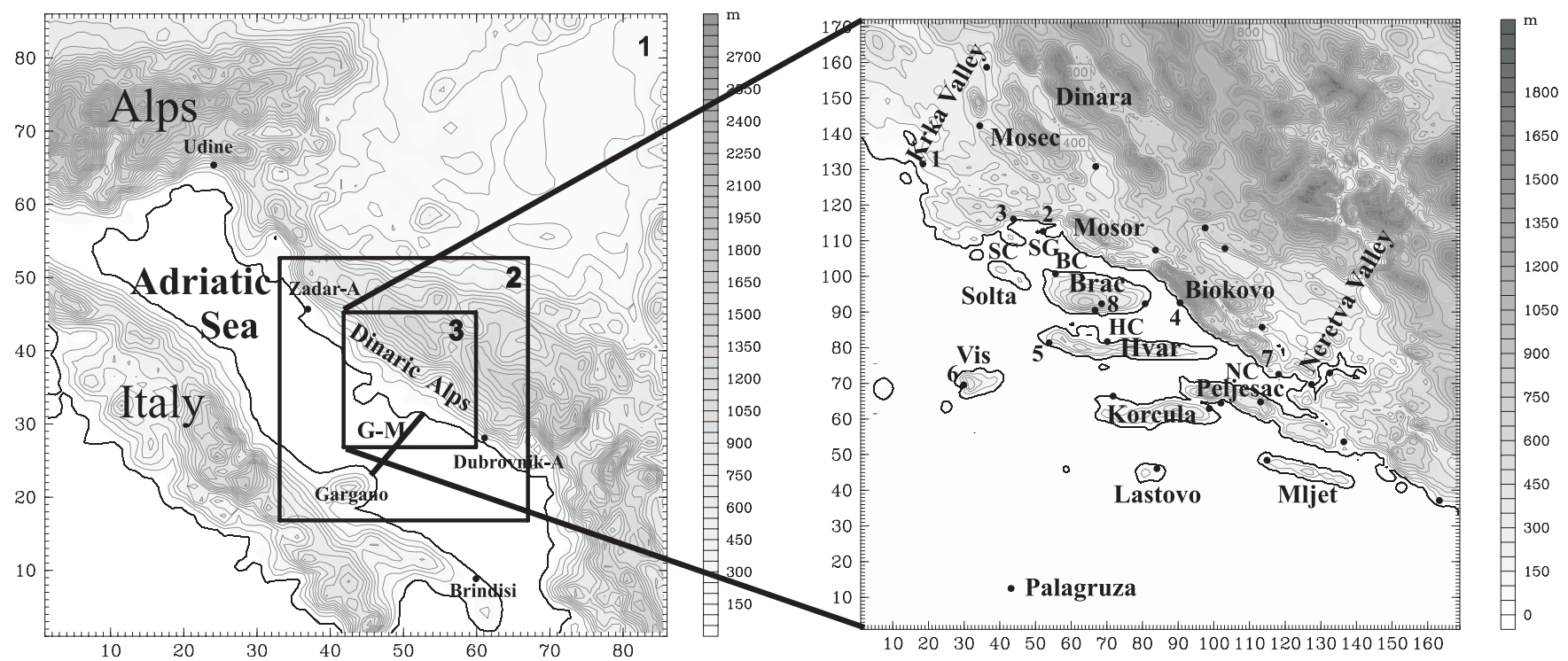

Fig. 1. (a) Configuration of nested model grids over the study area on the south-eastern Adriatic coast. Frames indicate the coarse-grid (1), mid-frame (2) and fine-grid (3) WRF model domains, respectively, with a radiosounding measuring sites at the Zadar airport (Zadar-A; $\left.44.12^{\circ} \mathrm{N}, 15.38^{\circ} \mathrm{E}\right)$, Udine $\left(46.03^{\circ} \mathrm{N}, 13.18^{\circ} \mathrm{E}\right)$ and Brindisi $\left(40.65^{\circ} \mathrm{N}, 17.93^{\circ} \mathrm{E}\right)$. (b) The fine-grid domain with positions of the measuring sites; hourly meteorological measurements (numbered stations from 1-8, see also Table 1) and climatological measurements (full black circles). The highest coastal mountain is Biokovo ( $1760 \mathrm{~m}$ a.m.s.l.) and the largest island is the island of Brač. Topography contours are given every $100 \mathrm{~m}$ between 0 and $1900 \mathrm{~m}$.

northern and southern Adriatic (Klaić et al., 2009). Klaić et al. (2009) investigated the interaction of the synoptically forced south-eastward Etesian winds with the SLB during two multiday summertime periods over the Adriatic. Using ALADIN at an 8-km resolution, they revealed asymmetry in the airflow along the Adriatic-basin axis due to the different topographic characteristics of the two coasts. Along the western Adriatic, daytime breezes were weaker and, consequently, of lesser horizontal extent than their eastern counterpart. Although they found that the SLB was generally enhanced by additional topographic forcing and channelling effects along the eastern Adriatic, they did not focus on the small scale features in the wind field.

A certain number of authors investigated the SLB at the western Adriatic. Analytically and numerically, Federico et al. (2000) investigated interactions of the SLB with mountain-valley thermal contrasts over the mountainous peninsula Calabria. Melas et al. (2000) found the major role of the topography for local nighttime thermally induced wind patterns over Sardinia. A numerical study performed by Caballero and Lavagnini (2002) revealed the structure and importance of the sea breeze (SB) interaction with the upslope wind in the greater Rome area. The influence of the SLB on the transport of photochemical oxidants and ozone accumulation along the western Adriatic coast can be found in Fortezza et al. (1993) and Mangia et al. (2010).

In the last few decades, certain climatological and mesoscale characteristics of the thermal wind patterns along the eastern Adriatic coastline have been described by such authors as Makjanić (1958), Orlić et al. (1988), Heimann (2001), Penzar et al. (2001), Lukšić (2004), Trošić et al. (2006) and Prtenjak and Grisogono (2007). These studies, among others, revealed that the energy of the SLB increases with lower latitudes (Orlić et al., 1988) along the east Adriatic coast where the SLB is more frequent (Penzar et al., 2001). Recent numerical modelling studies (e.g., Nitis et al., 2005; Prtenjak et al., 2006, 2008) have extensively discussed the formations of small-scale features during pure SLB events along the north-eastern Adriatic where the topography highly influences the SLB. According to numerical simulations, mountains decrease the maximum SB speed, but increase the SB depth and the depth of whole SB circulation. The SLB is more frequent in topographically complex environments because of its interactions with slope winds. The simulations showed many small-scale formations in the wind field that revealed SLB circulations: several convergence zones $(\mathrm{CZs})$ above the peninsula and islands, the baroclinic coastal jet-like flow within a sea channel, as well as small scale eddies within larger bays. According to air quality studies, it appears that such summer wind characteristics occasionally are associated with (very) high ozone levels (Prtenjak et al., 2009).

The obtained results of all abovementioned SLB-related studies allow many conclusions about the thermal winds along the Adriatic in general, predominately for the northern Adriatic region. However, knowledge of small-scale wind 
characteristics is significantly limited because the particulars of the horizontal and vertical SLB structure are closely related to the local topography (e.g., mountains, gaps, islands). A generalisation of known results to other, even more complex, topographic areas is always questionable. For now, there is no detailed systematic 3-D time-dependent study of small-scale variability in the wind field for the south-eastern Adriatic, despite the fact that (1) the SLB is more frequent and stronger in this area than along the north-eastern Adriatic (Penzar et al., 2001; Klaić et al., 2009) and (2) the coastline is very complex with three airports in the area (in Split, at the island of Brač and in Dubrovnik). In view of what is mentioned above, knowledge of fine and potentially serious mesoscale features, like CZs, can be highly useful in planning the air transport activities. Detection and forecast of rapid reversal of wind direction as well as strong updrafts at CZs may have a significant effect on the light aircraft climbing (and taking off) from the airfield. Therefore, we focus here on the complex, evolving 3-D flow structure of one SLB episode along the south-eastern Adriatic. For this purpose, we analyse the SLB case using the available measurements (in situ, radiosonde, sodar and satellite data) and a nonhydrostatic numerical mesoscale model at the fine grid spacing. Consequently, the coastal geometry, topography and landuse data are more precise than in Klaić et al. (2009). The main aim is to reveal the temporal and spatial evolutions of small-scale wind formations. The need for improving knowledge of SLB is motivated first, by their possible impact on air traffic, and second, for air quality studies.

\section{Study area}

The middle and southern part of the exceptionally narrow Croatian coast is separated from the hinterland by high mountains (Fig. 1), with the highest peak at $1913 \mathrm{~m}$ above sea level (a.s.1.). In this area numerous karstic rivers flow into the sea from the mountainous hinterland. The largest rivers are the Krka River, which enters into the sea close to the town of Šibenik (station 1 in Fig. 1), and the Neretva River, which flows into the sea near Ploče (station 7 in Fig. 1). The city of Makarska (station 4 in Fig. 1) is situated at the foot of the highest coastal mountain of Biokovo (1762 m, a.s.1.). Northwest from Biokovo is the city of Split (station 2), which lies $25 \mathrm{~km}$ from the Split airport (station 3). This region is also littered with numerous peninsulas and islands. The long and narrow islands (e.g., Hvar; the long axis lying parallel with the mainland coast) rise rather abruptly to elevations of a few hundred metres. The exception is the largest island, Brač (778 $\mathrm{m}$ a.s.1.), and the largest and most steep peninsula in the area, Pelješac (961 $\mathrm{m}$ a.s.l.). Vidova gora is the highest peak not only of the island of Brač, but also of all islands in southeastern Adriatic. Another airport in the area (the Brač airport, station 8 in Fig. 1) is situated in the south on the very hilly part of the island, while the north-eastern part of the island is the lowest. Komiža (station 6 in Fig. 1) is placed in a bay on the western coast of the distant island of Vis at the foot of the 600-m-high mountain.

\section{Background}

Although winds in the south-eastern Adriatic (Fig. 1) have been recorded in historical chronicles from Roman times, the knowledge and understanding of SLB systems has been highly limited by a number of factors. However, historical chronicles reveal that local inhabitants of the south-eastern Adriatic have made use of wind power by constructing the coastal wind mills since the beginning of the nineteenth century. For example, on the island of Brač (Fig. 1), 125 windmills were counted, and it seems that the local daytime thermally driven winds are the most optimal type of winds for exploitation. Valuable contributions to the knowledge of the south-eastern Adriatic thermal winds can be found in the work of authors such as Makjanić (1958), Lukšić (1995, 2004), Pandžić and Likso (2005) and Trošić et al. (2006). Still, the existing SLB analyses are mostly based on the in situ measurements in three terms (at 07:00, 14:00, and 21:00 h local time). For example, the near-surface measured SB in the central portion of the eastern Adriatic coast (in Split, station 2 in Fig. 1) originates from a SW direction with an average strength of 2.6 Bf. As determined from the (only) pilot-balloon measurements (Makjanić, 1958) above the same station, the vertical scale of the summer mature SB is about $1000 \mathrm{~m}$ with a maximum wind speed of $200-300 \mathrm{~m}$. Figure 2 shows the climatological observed surface wind vectors $\left(\mathrm{m} \mathrm{s}^{-1}\right)$ calculated for the south-eastern Adriatic during the period 1948-1994 (according to Lukšić, 2004). The land breeze (LB) is relatively weak and usually comes from the north-eastern direction (Fig. 2b). During the day, while costal measuring sites display the development of the southwesterly SB, distant island measuring sites show an influence of other flow/terrain features on the daytime winds (e.g., the Etesian wind). The same author (Lukšić, 1995) hypothesised that several SB systems existed over the island of Mljet at different spatial and temporal scales. However, the hypothesis relied only on the climatological dataset in three terms, mentioned above, which is still insufficient to confirm the above assumption.

\section{Model overview}

A description of the three-dimensional nonhydrostatic mesoscale meteorological Weather Research and Forecasting (WRF-ARW) model may be found in Michalakes et al. (2004), Kain et al. (2006), Skamarock et al. (2005), Jimenez-Guerrero et al. (2008) and Skamarock and Klemp (2008). In the present work, the model domain has three coupled horizontal grids. The coarse domain of $929 \mathrm{~km} \times 929 \mathrm{~km}(\Delta x=\Delta y=10.8 \mathrm{~km})$ covers the greater 

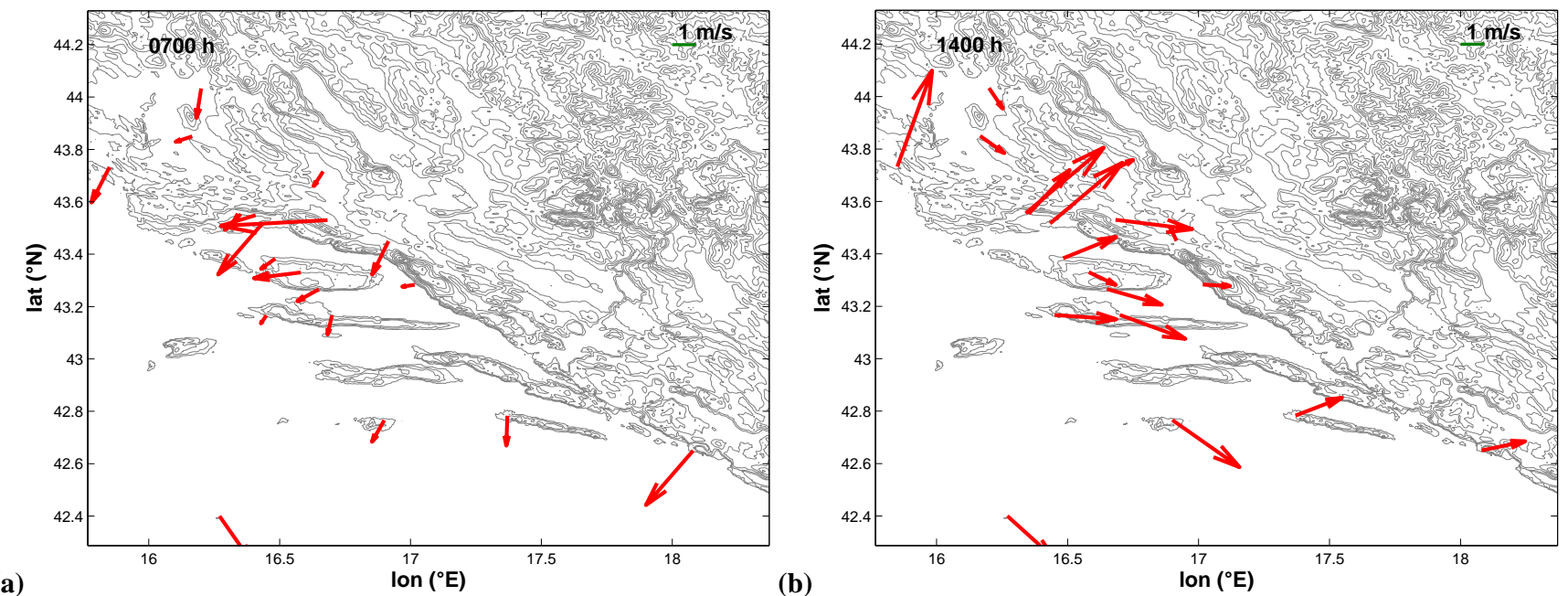

Fig. 2. The climatological observed surface wind vectors $\left(\mathrm{m} \mathrm{s}^{-1}\right)$ calculated for the selected SLB dataset for the south-eastern Adriatic for June and August 1948-1994 (a) for 07:00 LT and (b) for 14:00 LT (according to Lukšić, 2004). The measurements are in local time (LT means Central European Time $=\mathrm{UTC}+1 \mathrm{~h})$.

Adriatic Sea area (frame 1 in Fig. 1a). The finest domain, nested into the medium domain (with $\Delta x=\Delta y=3.6 \mathrm{~km}$; frame 2 in Fig. 1a), corresponds with an area of $172 \times 172$ points at a 1.2-km horizontal grid mesh, and it captures the south-eastern Adriatic. The vertical domain is discretised into 80 unevenly-spaced levels. For the inner domains, a topography and land-use data with a $30^{\prime \prime}$ resolution is applied.

The model used a two-way nesting technique. All domains used the WRF single-moment 3-class microphysics scheme, which predicted only a one cloud variable and one hydrometeor variable, either rainwater or snow. The Mellor-YamadaJanjic scheme for the planetary boundary layer, the Eta surface layer scheme based on the Monin-Obukhov theory and a five-layer thermal diffusion scheme for the soil temperature were also employed in this model setup. The longwave and shortwave radiation were calculated by the Rapid Radiative Transfer model and a Dudhia scheme, respectively. The Betts-Miller-Janjic cumulus parameterisation was applied only within a coarse $(10.8 \mathrm{~km})$ domain. Here, the model uses the Runge-Kutta 3rd order time integration scheme as well as a 5th order advection scheme in the horizontal and 3rd order in the vertical directions. The initial and boundary conditions were prescribed by the European Centre for Medium-Range Weather Forecasts (ECMWF) every $6 \mathrm{~h}$ at a 0.25-degree resolution.

\section{Results}

\subsection{Measurements}

To evaluate interactions between the SLB flows and the topography at different scales, we selected one SLB event that occurred on 24-25 April 2006. The chosen period has several advantages: (1) the influence of the Etesian wind is almost negligible in the area studied; (2) there are additional available measurements (e.g., sodar data); and (3) the synoptic conditions allow a comparison of the influence of two opposite large-scale winds (north-westerly versus south-easterly) on the development of SLB. According to the results given by Klaić et al. (2009) above target area, the Etesians can enhance the thermally induced wind speed by up to $50 \%$ (e.g., $2-3 \mathrm{~m} \mathrm{~s}^{-1}$, see their Fig. 8) and can redirect the onshore flow.

\subsubsection{Synoptic environment and radiosoundings}

According to both the diagnostic synoptic charts (not shown) and operational radiosondes along the Adriatic (Udine and Brindisi in Italy and Zadar airport in Croatia, Fig. 1), a region of the surface high pressure existed over south-eastern Europe, more precisely, over the wider Adriatic region. On 24 April 2006, the weak westerly (Udine and Zadar-airport, Fig. 3a) to north-westerly (Brindisi) wind dominated over the Adriatic. The wind speeds were lower than $10 \mathrm{~m} \mathrm{~s}^{-1}$ below $8000 \mathrm{~m}$ (Fig. 3b). At the same time, a cyclone had formed over the western Mediterranean and northern African coast (not shown). As the eastward cyclone approached closer to the Adriatic, the relatively weak south-easterly synopticwind gradually affected the whole Croatian coast (on 25 April 2006, Fig. 3c, d). In general, the observed surface air pressure gradients above the south-eastern Adriatic were weak (smaller than $5 \mathrm{hPa}$ ), allowing the development of local thermal circulation at the coasts. Still, the synoptic conditions on 24 April 2006 were more favourable for the SB formation. Figure 3 also provides a vertical comparison of measurements with modelled profiles taken from the nearest grid point in the middle domain (at corresponding time). The modelled wind profiles mostly follow the measured ones. 

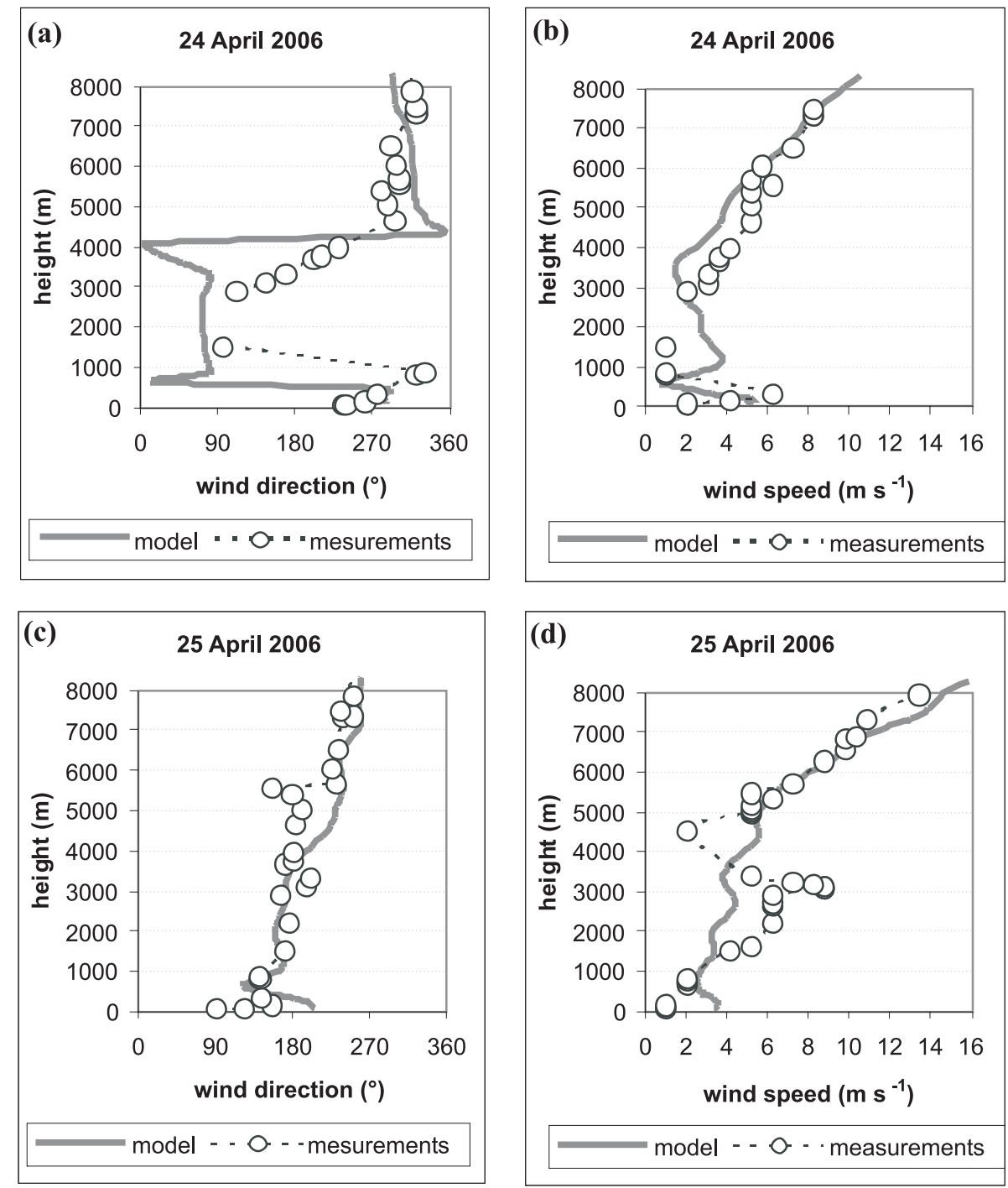

Fig. 3. Modelled (solid line) versus measured (circles) vertical profiles of (a, c) the wind direction and (b, d) the wind speed at the Zadar airport $\left(44.12^{\circ} \mathrm{N}, 15.38^{\circ} \mathrm{E}\right.$, see Fig. 1a) from the soundings launched at 12:00 UTC (13:00 LT) on 24 April 2006 and 25 April 2006 , respectively. For the comparison, the nearest model grid point from the middle domain is used.

Larger discrepancies between measurements and model are on 25 April 2006 (Fig. 3d), when the model failed to completely reproduce the measured variations of wind speed (between 1500 and $5000 \mathrm{~m}$ ). However, the overall comparison shows that the model satisfactorily recreated the synoptic conditions.

\subsubsection{QuikSCAT measurements}

We also used the 10-m wind field above the Adriatic based on QuikSCAT scatterometer measurements at a 12.5$\mathrm{km}$ resolution (Fig. 4a). The data were obtained from Physical Oceanography Distributed Active Archive Centre (PO.DAAC) as a Level 2B Product (http://podaac.jpl.nasa. gov/PRODUCTS/p286.html) and subsetted for the Adriatic area. The instrument specification gives root mean square errors (RMSE) at a magnitude of $2 \mathrm{~m} \mathrm{~s}^{-1}$ and a $20^{\circ}$ direction without any bias. Based on a validation study focused on the coastal regions (Tang et al., 2004), QuikSCAT gives higher errors closer to the shoreline $(<80 \mathrm{~km})$ both in magnitude $\left(0.93 \mathrm{~m} \mathrm{~s}^{-1} \pm 1.83 \mathrm{~m} \mathrm{~s}^{-1}\right)$ and, especially, in direction $\left(4.71^{\circ} \pm 31.15^{\circ}\right)$. In the open sea it performs close to the specification. For the light winds $\left(<3 \mathrm{~m} \mathrm{~s}^{-1}\right)$ the error is even higher, especially for the wind direction (Tang et al., 2004). These limitations should be kept in mind when performing such comparisons. The modelled 10-m hourly wind from the middle domain was interpolated in time and space to conform to the daytime QuikSCAT satellite measurements at 17:08 UTC on 24 April 2006. As seen from Fig. 4b, above the open sea the wind speed is relatively low, not higher than 
(a)

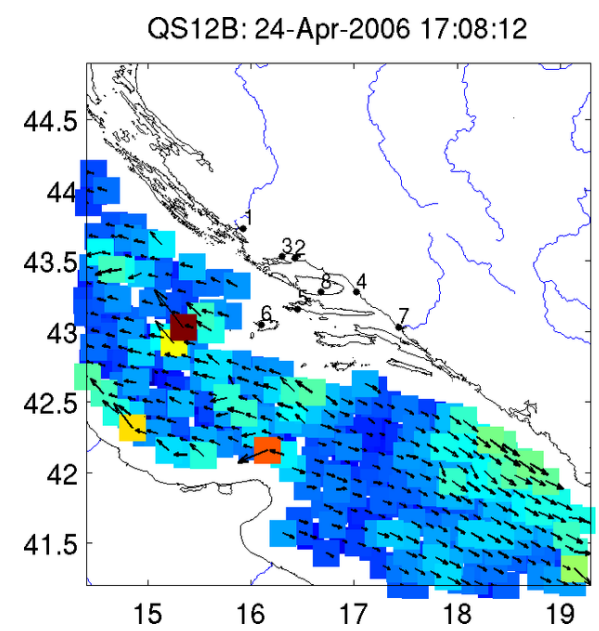

(b)

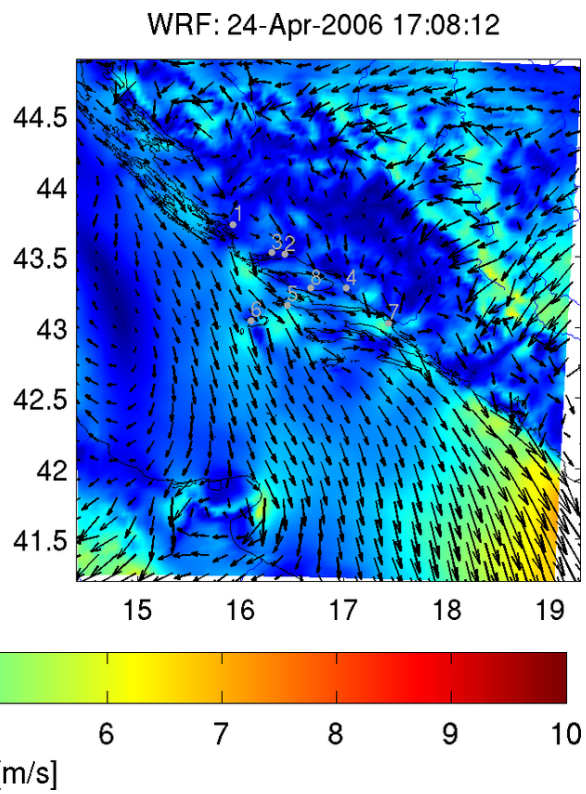

Fig. 4. (a) QuikSCAT 10-m winds and (b) modelled 10-m winds at 17:08 UTC (18:08 LT), 24 April 2006.

Table 1. Statistical indices associated with hourly meteorological variables provided by the meteorological sites (1-8) in Fig. 1 and modelled wind speed, wind direction and 2-m air temperature from the nearest land grid point in the finest domain, respectively: mean absolute error (MAE), root mean square error (RMSE), index of agreement $(d)$ and bias for 24-25 April 2006. Abbreviations for stations are $\breve{S}=\breve{S}$ ibenik, $\mathrm{S}-\mathrm{M}=$ Split-Marijan, $\mathrm{S}-\mathrm{A}=$ Split-airport, $\mathrm{M}=$ Makarska, $\mathrm{H}=$ Hvar, $\mathrm{K}=$ Komiža, $\mathrm{P}=\mathrm{Ploče} \mathrm{and} \mathrm{B-A=} \mathrm{Brač-airport.} \mathrm{The} \mathrm{main} \mathrm{characteristics}$ of the measurement sites include coordinates $\left(\phi\left({ }^{\circ} \mathrm{N}\right), \lambda\left({ }^{\circ} \mathrm{E}\right)\right)$, altitude $(h)$, the distance from coast $(d)$ and measurements heights $(h a)$.

\begin{tabular}{|c|c|c|c|c|c|c|c|c|c|c|c|c|}
\hline \multirow[b]{2}{*}{ Station $\left(\phi\left({ }^{\circ} \mathrm{N}\right), \lambda\left({ }^{\circ} \mathrm{E}\right), h, d, h a\right)$} & \multicolumn{4}{|c|}{ Wind speed $\left(\mathrm{m} \mathrm{s}^{-1}\right)$} & \multicolumn{4}{|c|}{ Wind direction $\left(^{\circ}\right)$} & \multicolumn{4}{|c|}{ Temperature $\left({ }^{\circ} \mathrm{C}\right)$} \\
\hline & MAE & RMSE & $d$ & bias & MAE & RMSE & $d$ & bias & MAE & RMSE & $d$ & bias \\
\hline $1 . \check{S}\left(43.7^{\circ}, 15.9^{\circ}, 77 \mathrm{~m}, 700 \mathrm{~m}, 9 \mathrm{~m}\right)$ & 1.1 & 1.2 & 0.8 & 1.2 & 58 & 70 & 0.9 & 15 & 2.1 & 2.4 & 0.8 & 0.0 \\
\hline 3. S-A $\left(43.5^{\circ}, 16.3^{\circ}, 21 \mathrm{~m}, 2500 \mathrm{~m}, 8 \mathrm{~m}\right)$ & 0.8 & 1.1 & 0.7 & -0.1 & 50 & 62 & 0.9 & -4 & 2.6 & 3.3 & 0.8 & -1.4 \\
\hline 4. $\mathrm{M}\left(43.2^{\circ}, 17.0^{\circ}, 9 \mathrm{~m}, 100 \mathrm{~m}, 20 \mathrm{~m}\right)$ & 0.7 & 0.7 & 0.7 & 0.3 & 68 & 84 & 0.8 & -3 & 1.9 & 2.3 & 0.9 & -0.3 \\
\hline 5. $\mathrm{H}\left(43.1^{\circ}, 16.4^{\circ}, 20 \mathrm{~m}, 80 \mathrm{~m}, 12 \mathrm{~m}\right)$ & 1.2 & 1.6 & 0.6 & 1.1 & 45 & 60 & 0.9 & 7 & 1.3 & 1.6 & 0.9 & 0.3 \\
\hline 8. B-A $\left(43.2^{\circ}, 16.6^{\circ}, 541 \mathrm{~m}, 3000 \mathrm{~m}, 10 \mathrm{~m}\right)$ & 1.3 & 1.5 & 0.6 & 0.8 & 50 & 60 & 0.9 & 27 & 2.7 & 3.0 & 0.8 & -0.3 \\
\hline
\end{tabular}

5-6 $\mathrm{m} \mathrm{s}^{-1}$ (except for a few outliers). However, the difference in magnitude of the QuikSCAT estimated and modelsimulated wind is within the uncertainties for this kind of measurement. Overall, the wind field magnitude error is $0.03 \pm 1.73 \mathrm{~m} \mathrm{~s}^{-1}$, while the error in direction is much higher, mostly due to the higher direction errors for light winds (see above). The QuikSCAT field revealed two nearly opposite wind regimes northward and southward from the GarganoMakarska line (see G-M line in Fig. 1a). Southward from the G-M line, the north-westerly flow had an estimated maximum wind speed $\left(6-7 \mathrm{~m} \mathrm{~s}^{-1}\right)$ close to the south-eastern Adriatic (Montenegrin) coast. The maximum wind speed can be observed in the simulation as well, although it is stronger than the QuikSCAT wind. East of the Gargano Peninsula, but still very close to the coast (and therefore seen only in model, Fig. 4b), increased wind speeds are also present. These wind characteristics are highly consistent with the results of Klaić et al. (2009). Northward from the G-M line, the model satisfactorily reproduced the south-westerly winds close to the Italian coast. However, the west-north-westerly winds close to the Croatian coast (indicated by radiosoundings, Fig. 3a), with a silent area between $44^{\circ} \mathrm{N}$ and $42.5^{\circ} \mathrm{N}$ along the central basin axis (again in agreement with Klaić et al., 2009), are not visible in QuikSCAT's retrieved winds (Fig. 4). As 

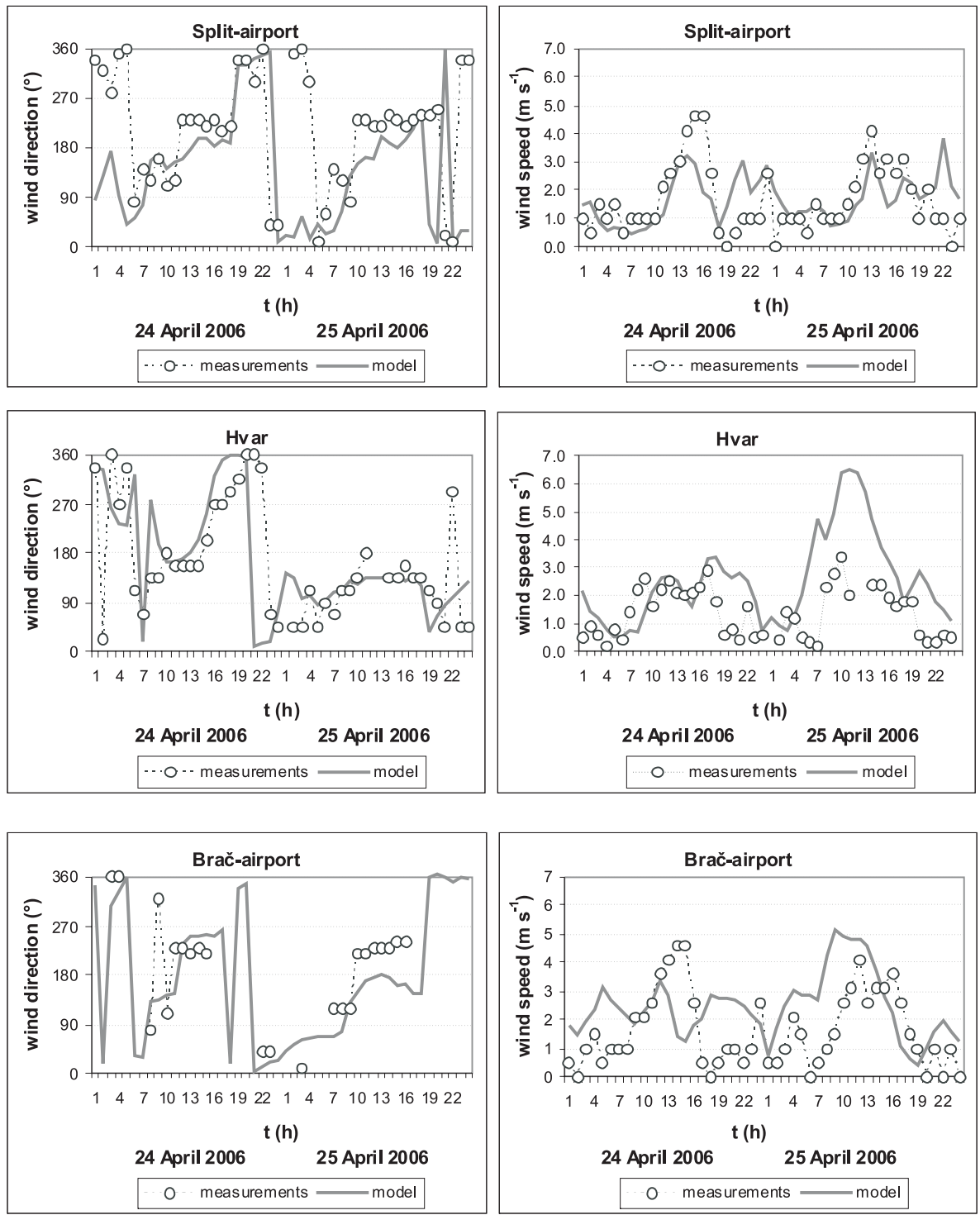

Fig. 5. Comparison between measured (circles) and modelled (solid line) wind direction (left) and wind speed (right) for three main meteorological stations: the Split airport, Hvar and the Brač airport (numbered 3, 5 and 8 in Fig. 1b, respectively). The measurements are in local time (LT means Central European Time $=\mathrm{UTC}+1 \mathrm{~h}$ ). For comparison, the closest land grid point is used. The amount of available measured wind direction data at the Brač airport is somewhat reduced.

mentioned before, due to the low wind speeds $\left(<3 \mathrm{~m} \mathrm{~s}^{-1}\right)$ all QuikSCAT data are of reduced quality and the wind direction in affected area is most probably not completely retrieved. Presumably, both QuikSCAT and WRF were biased in opposite direction which produced higher discrepancy in the area above the G-M line.

\subsubsection{In situ meteorological measurements}

This study mainly focuses on examination of the wind structure along the south-eastern Croatian coast. At the surface, the main meteorological stations (Fig. 1) provide hourly measurements of the near-surface wind and temperature.
Figure 5 shows how the model reproduced the measured near-surface winds at three stations (the Split airport, Hvar and the Brač airport). The calculated statistical indices for the main meteorological stations were calculated for measurements and the model (at $1.2 \mathrm{~km}$ resolution) using the closest land grid points in corresponding time (Table 1). All measuring sites are close to the sea. The in situ measurements and the simulation show that the onshore flow was established in the coastal area at around 10:00 LT (Local Time here means Central European Time $=\mathrm{UTC}+1 \mathrm{~h})$. The onshore flow lasted, on average, eight consecutive hours during the daytime (Fig. 5). The measured SB intensity increased 


\section{(a)}
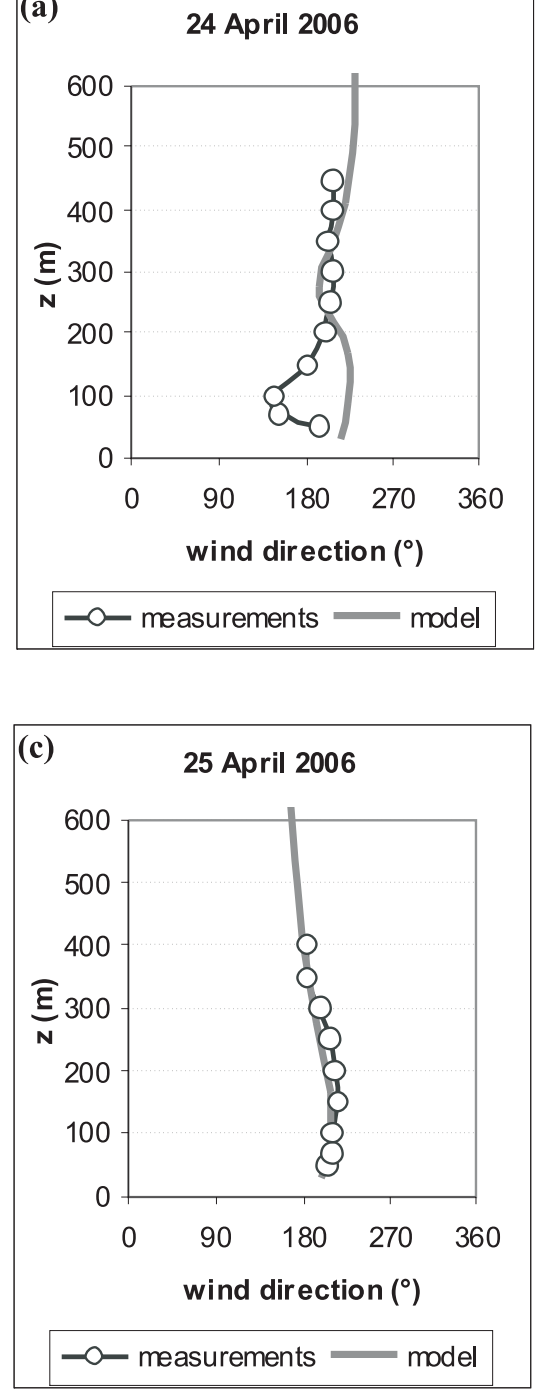
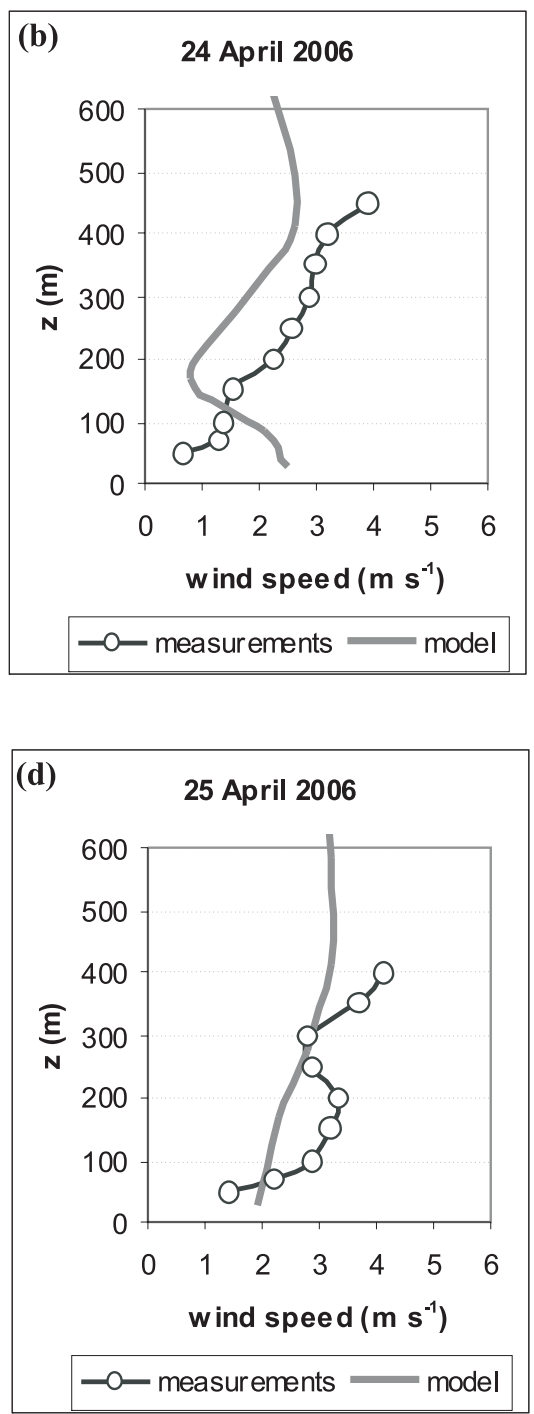

Fig. 6. Modelled versus measured vertical profiles of (a, c) wind speed and (b, d) wind direction from the Scientic MFAS sodar at the Split airport $\left(43.53^{\circ} \mathrm{N}, 16.30^{\circ} \mathrm{E}\right.$; station 3 in Fig. 1b) at 14:00 LT on 24 April 2006 and 25 April 2006, respectively. For comparison, the closest land grid point is used.

from approximately $2 \mathrm{~ms}^{-1}$ to a maximum of $5 \mathrm{~m} \mathrm{~s}^{-1}$ at the airport stations from the SW direction, representing a "typical” SB development (Makjanić, 1958; Lukšić, 2004). The observed SB agrees with the simulated SB, although the model underestimates the SB's strength on 24 April 2006 (e.g., the Split airport and the Brač airport), and overestimates its strength on 25 April 2006 (e.g., the Brač airport and Hvar). However, over the Split airport, the near-surface measurements indicate the formation of two SB systems because there is an abrupt exchange of SB direction from southeast (SE) to south-south-west (SSW) after 13:00 LT (Fig. 5). During nighttime hours, the model simulates fairly well the weak north-easterly flow as the LB with the maximum speed not exceeding $3 \mathrm{~m} \mathrm{~s}^{-1}$ either by the measurements or by the model. Table 1 shows statistics for the employed model, namely, mean absolute error (MAE), RMSE, the index of agreement, the $d$-index (e.g., Willmott, 1982; Mastura, 2009) and bias. The wind speed, wind direction and temperature are satisfactorily reproduced by the model with deviations similar to the other mesoscale studies of the same phenomenon (e.g., Bastin and Drobinski, 2006; Prtenjak et al., 2006; Miao et al., 2009). In general, among the stations, the uncertainty between the measured and the modelled $10-\mathrm{m}$ wind speeds are around $1.1 \mathrm{~m} \mathrm{~s}^{-1}, 1.4 \mathrm{~m} \mathrm{~s}^{-1}$, and $0.6 \mathrm{~m} \mathrm{~s}^{-1}$ for the MAE, the RMSE and the bias, respectively, with the $d$-index higher than 0.6. Despite the fact that for very low wind speeds most numerical models fail to reproduce winds completely over highly complex terrain (e.g., Baklanov and Grisogono, 2007), the wind directions are simulated acceptably with $d$-indices higher than 0.8 . However, 
the largest discrepancies for the temperature field are found in the overestimated minima and the underestimated maxima values during 24-h temperature cycle. The $d$-indices for temperature are also higher than 0.8. Despite differences between the modelled and measured data (presumably due to the smoothed topography), ability of the model to simulate the SLB is satisfactory, and overall agreement between the measured and modelled wind is still relatively good.

\subsubsection{Sodar data}

The examined period was also covered by sodar measurements. The sodar of the Scientific MFAS Series was installed at the Split airport, providing vertical soundings of wind speed and direction. The operation frequencies in the $2 \mathrm{kHz}$ band allow measurements ranging up to approximately $700 \mathrm{~m}$ for a spatial resolution of $10 \mathrm{~m}$. The wind speed and wind direction are shown in Fig. 6 for both examined days during the mature SB stage. On 24 April 2006, the measured wind direction revealed a veering of the wind vectors. This veering indicates a competition between two onshore flows, a SE flow below $200 \mathrm{~m}$ and a deeper SSW flow. However, the Coriolis force influences the veering of the wind vectors during the daytime in the Northern Hemisphere (e.g., Haurwitz, 1947; Sakazaki and Fujiwara, 2008). Here, the vertical structure confirms the dual SB formations already observed in the near-surface measurements. According to the flow interaction (not completely captured by the model), the measured wind speed is very low, and it deviates from the modelled wind speed by up to $1.5 \mathrm{~m} \mathrm{~s}^{-1}$ (taken from the closest grid point at matching time). However, above the lowermost $100 \mathrm{~m}$, the model reproduces the wind characteristics satisfactorily. On 25 April 2006, under less propitious large-scale conditions for SB development, the sodar wind measurements show a more or less similarly directed flow, compared to the previous day. The wind is blowing from the SSW direction near the surface and it progressively veers to the south above $300 \mathrm{~m}$. The maximum of the SB is located at $200 \mathrm{~m}$ in the SSW onshore flow. Although the wind speed is also very low near the surface, the model is in agreement with the measurements, despite a slight underestimation of the wind speed.

\subsection{Modelled daytime wind field characteristics}

In the previous section, an analysis of the different measurements showed the existence of the SLB in the studied area and the capability of the model in SLB reproduction. The time evolution of the thermally driven near-surface flow has already been represented in Fig. 5. Here, further details about the daytime general evolution of the thermally induced flow on 24 and 25 April 2006 are presented.

Before noon, the coastal circulation develops in all coastal and most island stations; the earliest is in the north-western area and the latest, with a two-hour delay, in front of the
Neretva Valley (not shown). In the early afternoon, the fullyformed daytime near-surface flow reaches its mature phase (Fig. 7). Spatially, the SBs have a variable intensity (3.5$5 \mathrm{~m} \mathrm{~s}^{-1}$ ) and direction (Fig. 7). Whereas the south-westerly flow dominated over the continental stations, the distant islands were mostly under the influence of the prevailing northwesterly flow (Fig. 7a, b), imitating the Etesians. This pattern is also in qualitative agreement with climatology (compare Figs. 2 and 7) and with Pandžić and Likso (2005). Due to the complex topography, the clear appearance of several intensive convergence zones $(\mathrm{CZs})$ can be observed in the wind field; these are situated above the islands and north-westward of the Split airport. Determined by the convergence of the surface wind, they also occur in the lees of mountains as a result of flow modifications on the coast and the SB passing through the mountain notches. Between the mainland and the island of Brač, a strong divergence zone occurs at the same time when CZs are created in other parts. All CZs vary in time and space regarding their strength and position. The CZs last until the stabilizing processes in the coastal environment overcomes the daytime differential heating, at about 18:00 LT. Despite opposite large-scale SE synoptic winds on 25 April 2006 (Fig. 7c, d), the general SB evolution over the mainland was rather similar to the previous day, and the main specific wind features formed again (Fig. 7b, d). Differences in the wind characteristics between the two consecutive days become greater with increasing distance from the main coastline. In light of these factors, and due to the highly particular observed wind characteristics, we continue with an analysis of the most intriguing features obtained by the model. These features are the CZs close to the airports (the Split airport and the Brač airport), the channelling flow and the small scale eddies.

\subsubsection{Convergence zone near the Split airport}

From station 1 to the Split airport, the shape of the coastline is significantly curved, alternating between a concave and convex (see Fig. 1b). The result is a complex wind pattern that is highly correlated with the coastline's shape (Fig. 8a), with convergent $\mathrm{SBs}$ over convex and divergent SBs over concave regions (McPherson, 1970). During the daytime, the westerly thermally induced flow developed in a 400-mdeep layer over the Krka Valley. As used by many authors (e.g., Banta et al., 1993; Banta, 1995; Steyn, 1998; Bastin et al., 2005), the depth of the SB flow is estimated as the height where the flow reversal occurs and the inland penetration of the SB is revealed by the breeze's front position. Over the Split airport, the onshore flow blows first from the SE direction in the lowermost $300 \mathrm{~m}$, representing the superposition of the upslope wind and the SB. The maximum near-surface onshore speeds are up to $5 \mathrm{~m} \mathrm{~s}^{-1}$. Soon after the western and SE onshore systems developed, they collided creating a CZ that is almost perpendicular to the local coastline over its convex part. This $\mathrm{CZ}$ is placed $15 \mathrm{~km}$ from the 
(a)
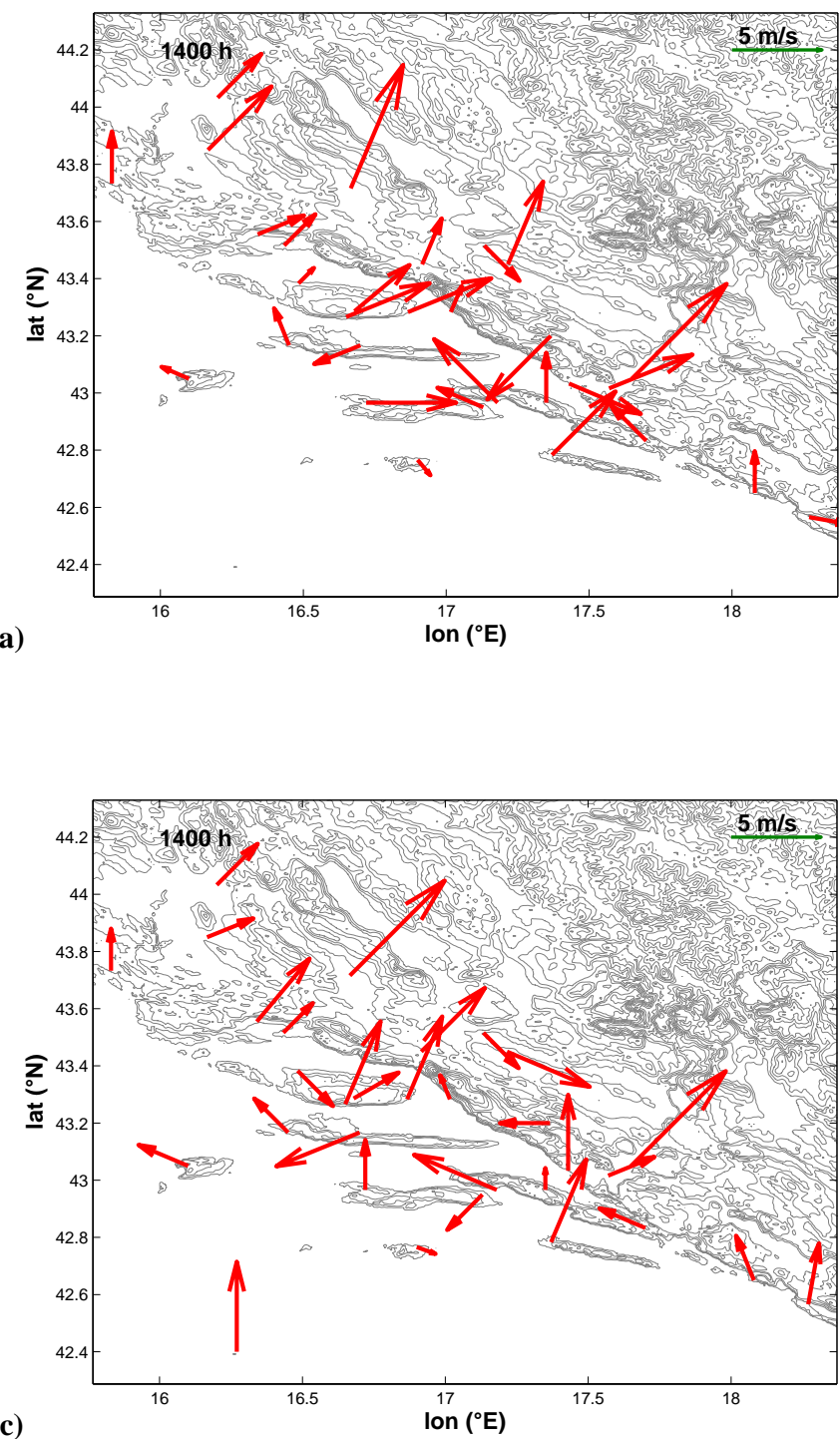

(b)

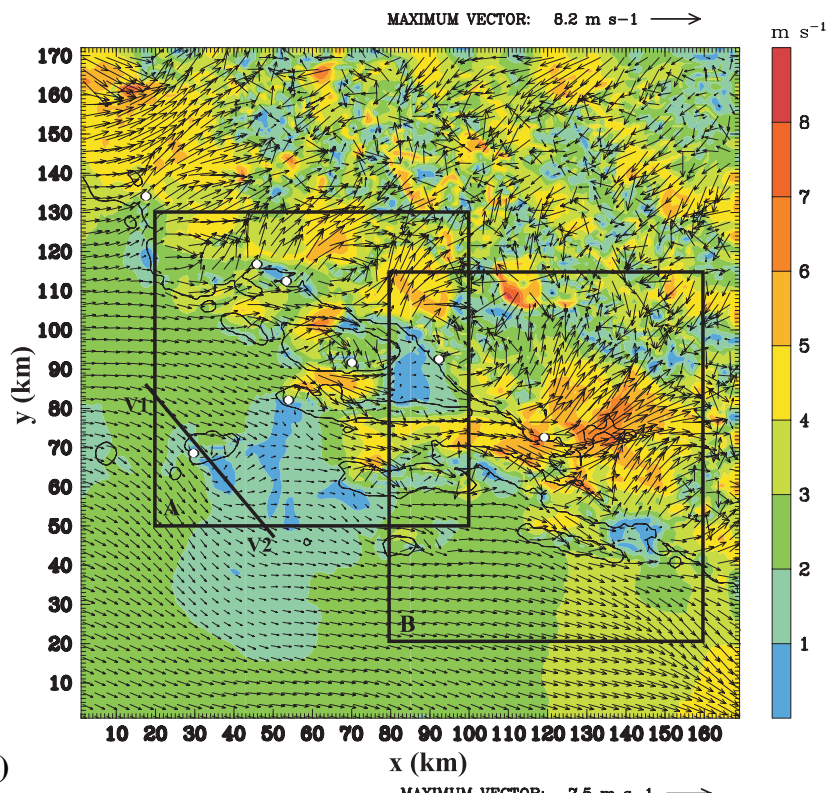

(d)

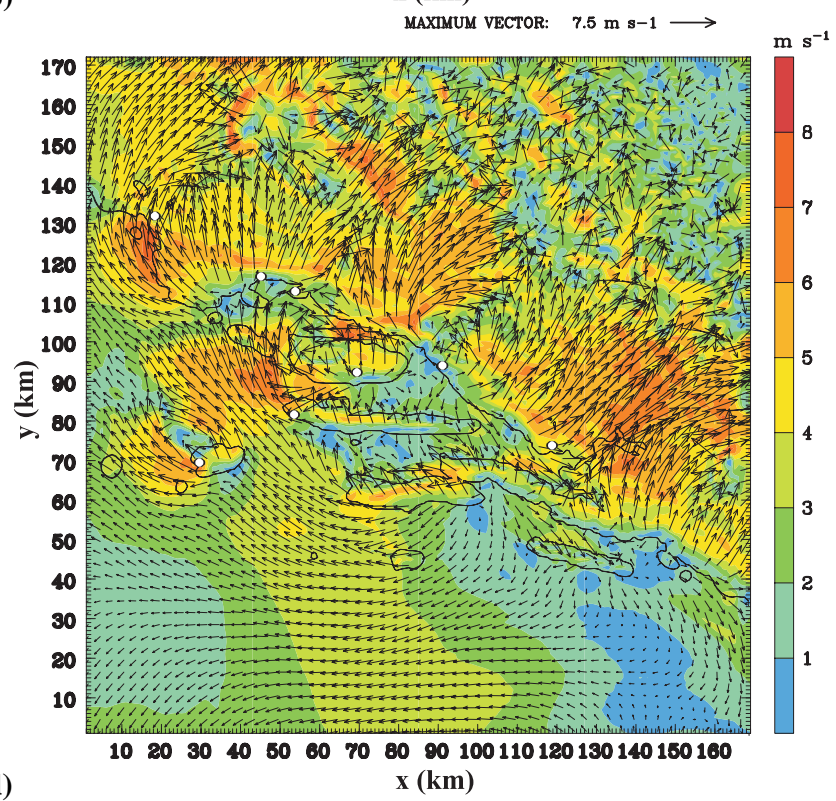

Fig. 7. Measured 10-m wind vectors ( $\mathrm{m} \mathrm{s}^{-1}$ ) at 14:00 LT for (a) 24 April 2006 and (c) 25 April 2006 from meteorological and climatological stations (dots in Fig. 1b). Modelled WRF wind field in the finest domain at 14:00 LT for (b) 24 April 2006 and (d) 25 April 2006. The wind vectors are given at a horizontal resolution of $3 \mathrm{~km}$ with reference vectors near the upper right-hand corner. White circles denote measuring sites (see also Table 1).

Split airport. During the afternoon (Fig. 8b, d), the westerly $\mathrm{SB}$ deepens (up to $800 \mathrm{~m}$ ) and strengthens (to $6 \mathrm{~m} \mathrm{~s}^{-1}$ ), occupying a space more than $40 \mathrm{~km}$ above the complex terrain and $100 \mathrm{~km}$ over the sea. Slightly faster than in the measurements over the Split airport, the shallow layer of the SE wind was overwhelmed by another, deeper SSW thermally induced flow $(\sim 800 \mathrm{~m})$. The $\mathrm{CZ}(\sim 1100 \mathrm{~m}$ deep and associated with a turbulent kinetic energy of $0.9 \mathrm{~m}^{2} \mathrm{~s}^{-2}$ ) changed its position, proceeding westward with a maximum speed of $\sim 1 \mathrm{~m} \mathrm{~s}^{-1}$. Due to highly complex topography, this after- noon SB penetration is somewhat slower than that observed for, e.g., SE France (Bastin and Drobinski, 2006) and is quite similar to that estimated for the north-eastern Adriatic (Prtenjak et al., 2006). Now the CZ is more parallel to the westeast axis, placed no more than $4 \mathrm{~km}$ from the Split airport (Fig. 8d). The origin of this exchange between the two SBs with variable depths at different timescales is due to gradient pressures caused by local-scale and larger-scale temperature contrasts (Fig. 8a-c). A similar effect was shown by Banta et al. (1993) and Bastin and Drobinski (2006). However, in 

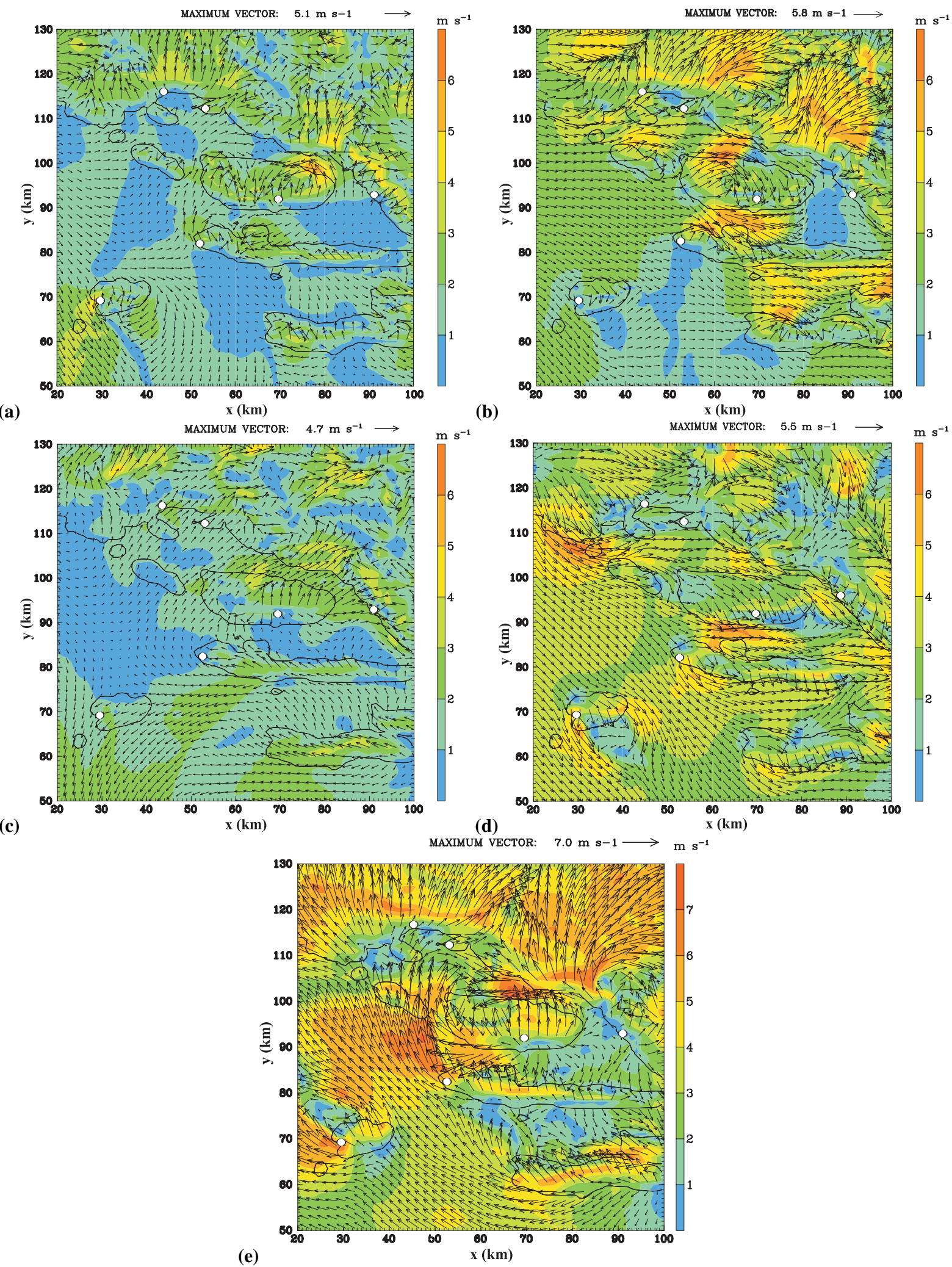

Fig. 8. A close-up of the wind distribution within frame A in Fig. 7b at (a) 11:00 LT on 24 April 2006 at 10 m a.g.1., (b) 14:00 LT on 24 April 2006 at $10 \mathrm{~m}$ a.g.1., (c) at 14:00 LT on 24 April 2006 at $650 \mathrm{~m}$ a.g.1., (d) at 17:00 LT on 24 April 2006 at 10 m a.g.1. and (e) 14:00 LT on 25 April 2006 at $10 \mathrm{~m}$ a.g.l., respectively. The wind speed is depicted by filled areas (legend on the right) with a $1 \mathrm{~m} \mathrm{~s}^{-1}$ interval. White circles denote measuring sites (see also Table 1). 
contrast to Bastin and Drobinski (2006), and similar to Banta et al. (1993) and Banta (1995), the more shallow and deep onshore flows are merged together, and the shallow SB is no longer evident in the late afternoon. The next day, largerscale SE winds caused some differences during the day. The thermally induced flow from the SE direction is enhanced by the synoptic wind (up to $7 \mathrm{~m} \mathrm{~s}^{-1}$ ), retarding the daytime $\mathrm{CZ}$ displacement towards the Split airport. At 14:00 LT, an almost stationary $\mathrm{CZ}$ is caused by an impinging flow, which is located more northward than on 24 April and is $30 \mathrm{~km}$ from the airport station (Fig. 7d). In the late afternoon, at around 17:00 LT, the CZ weakens and the temperature gradient gradually becomes closer to zero.

\subsubsection{Convergence zone near the Brač airport}

As a result of the interactions of the coastal circulation and the upslope winds, onshore flows also form on the islands. At around 08:00 LT, the CZ forms due to merging 300-mdeep thermally induced flows over the island of Brač (not shown). At 11:00 LT, the onshore flow penetrates inland, where further progress is stopped by the highest island peak, Fig. 8a. Determined by the mountainous terrain, the $\mathrm{CZ}$ is highly curved in space, being placed from the north-western part of the island toward the eastern and lowest part. The $\mathrm{CZ}$ is approximately $600 \mathrm{~m}$ deep and is characterised by an updraft of $\sim 0.5 \mathrm{~m} \mathrm{~s}^{-1}$ at a distance less than $2 \mathrm{~km}$ from the Brač airport. Symmetrically, over the western and the eastern part of the island, the CZ's shape is affected by small eddies. While the western eddy had an anticyclonic rotation, the second eddy had an opposite rotation due to the topography. Similarly to what we observed near the Split airport, the westerly SB gradually strengthens and accelerates over the western part of the island due to a larger-scale temperature gradient between the mainland and the sea (Fig. 8b). The westerly flow forms two cores of maximum near-surface wind speeds (over $6 \mathrm{~m} \mathrm{~s}^{-1}$ ) northward and southward of the island. Simultaneously, the incoming wind absorbs the almost opposite morning flows. Now, over the eastern part of the island, the onshore flow suddenly changes direction from the morning east-northeast to the afternoon west-northwest direction within the lowermost $400 \mathrm{~m}$. The next 600-m-deep layer is characterised by the interaction of the return current of the shallow SB above the island and the larger SB flow towards the mainland (Fig. 8c). The $\mathrm{CZ}$ reached its maximum around early afternoon, occupying a space of $1000 \mathrm{~m}$ above land, when the convergence in the near-surface wind and the divergence above resulted in $1 \mathrm{~m} \mathrm{~s}^{-1}$ vertical velocities. Up to 17:00 LT, Fig. 8d, while the westerly SB moves the northern part of the $\mathrm{CZ}$ eastward, the rest of the $\mathrm{CZ}$ is displaced southward. The north-westerly flow dominates over the island and the $\mathrm{CZ}$ is over the airport, although its strength (e.g., associated updraft) is considerably reduced. It diminishes in the next hour. On the other islands, the CZs are almost stationary, being dictated by the local terrain and with a simi- lar lifetime. The situation changes on 25 April 2006, as the south-westerly synoptic-scale wind combines with the onshore flow (Fig. 8e). Northward and southward of the island, the easterly wind is accelerated (up to $8 \mathrm{~m} \mathrm{~s}^{-1}$ ), resulting in three CZs. Two of these had a maritime origin, northward and westward of the island of Brač. The last, continental CZ with the concave shape was rather distant from the airport and was limited to the north-eastern part of the island.

\subsubsection{Distant islands}

The more distant islands mostly fail to develop thermally induced circulations because they represent a small active area that is under the direct influence of the prevailing synoptic flow. However, on 24 April 2006, the shallow flow over the open sea came from the north-west and the island of Vis was tall (up to $600 \mathrm{~m}$ ) and large enough to create a significant airflow disturbance (Fig. 8). In general, when a shallow flow arrives at an obstacle, it bypasses the obstacle and rotates and then weakens, creating the so-called lee-wake and vortices (e.g., Smith and Grubišić, 1993; Epifanio and Durran, 2002). Here, the splitting of flow around the island generates accelerated winds and shear zones over the western and eastern flank of island (Fig. 8a, d). The reversed flow exists over the southern part of the island of Vis within the lowermost $300 \mathrm{~m}$ layer. Although always present, on 24 April 2006 the number, position and spatial dimension of the lee vortices vary owing to variable upstream wind conditions as well as the diurnal heating of the island. The weakest activity of the lee vortices is around early afternoon (Fig. 8b). The reason for this flow structure is the stable stratification on the windward side and relatively high barriers. We calculated the upstream Froude number $\left(F r=V / N h_{\mathrm{m}}\right)$ as the ratio between the upstream wind velocity $(V)$, the Brunt-Väisälä frequency $(N)$ and height of the obstacle $\left(h_{\mathrm{m}}\right)$. In Fig. 9a, the computed upstream Froude number is not higher than 0.3 , suggesting the subcritical conditions are achieved and, thus, the flow may be blocked. Similar currents are observed around another southern distant island (not shown). On 25 April 2006, over the northern part of the island of Vis (Fig. 8e) orographic wakes and vortices formed due to the SE large-scale wind. Despite stronger synoptic wind, the subcritical conditions remain (i.e., $F r \sim 0.7$, Fig. 9b) and the formation of the wake and vortices is now closely tied to the low-level hydraulicjump-like feature in the island's lee.

\subsubsection{The Neretva Valley}

Additional attention is paid to the significant flow channelling in the valley of the Neretva River (seen in both the measured and modelled wind field, Fig. 7). The valley is an important agriculture region oriented southwest-northeast and perpendicular to the local coastline. At first, the valley is rather narrow, but after $10 \mathrm{~km}$ it becomes much wider. In this area in front of the mainland, many channels alternate 


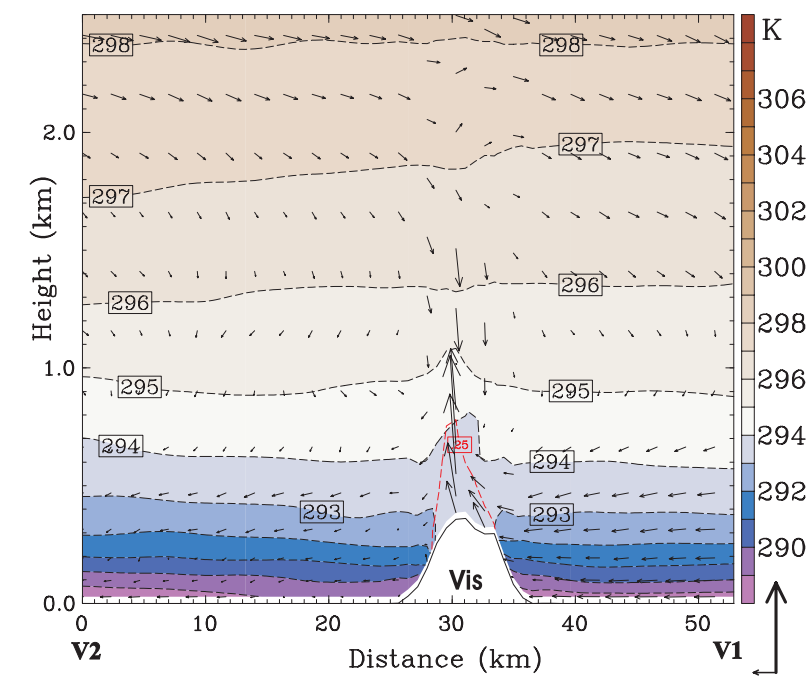

(a)

MAXIMUM VECTOR: $2.1 \mathrm{~m} \mathrm{~s}^{-1}$ (HORIZ) $44.1 \mathrm{~cm} \mathrm{~s}^{-1}$ (VERT)

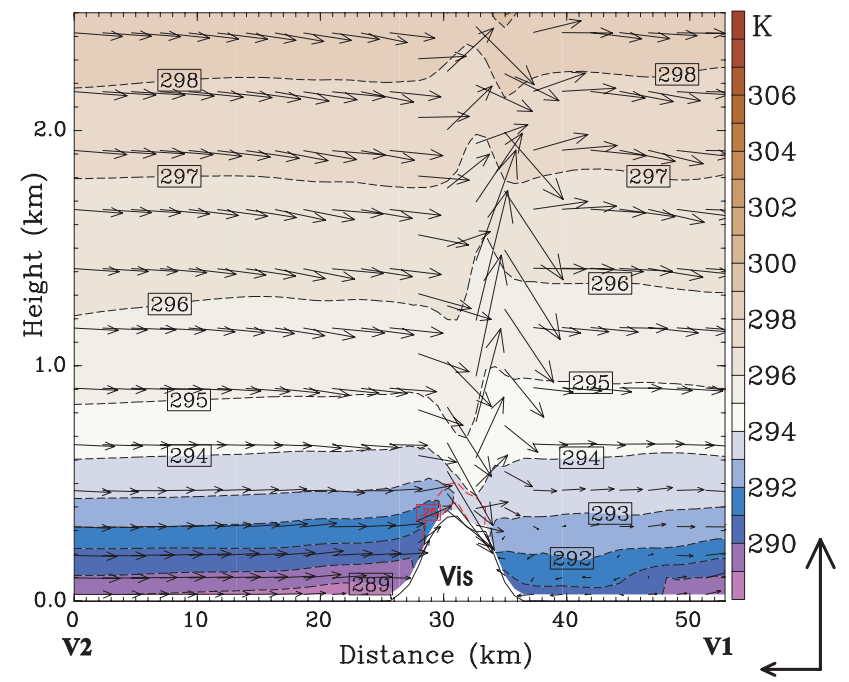

(b)

Fig. 9. Vertical cross-sections of the modelled wind $\left(\mathrm{m} \mathrm{s}^{-1}\right)$, potential temperature $(\mathrm{K})$ and turbulent kinetic energy $\left(\mathrm{m}^{2} \mathrm{~s}^{-2}\right)$ at $14: 00 \mathrm{LT}$ on (a) 24 April 2006 and (b) 25 April 2006 along V1V2 (see Fig. 7b) transecting the island of Vis. Arrows represent the wind vectors $\left(v_{h}\right.$, $w$ ) with the along-section horizontal $\left(v_{h}\right)$ and vertical $(w)$ wind components. The wind vectors are given at a horizontal grid spacing of $1 \mathrm{~km}$, with reference vectors near the lower right-hand corner. The potential temperature is depicted by filled areas (legend on the right) with a $1 \mathrm{~K}$ interval. The turbulent kinetic energy is shown by the dashed lines every $0.25 \mathrm{~m}^{2} \mathrm{~s}^{-2}$.

with exceptionally elongated islands that are almost parallel to the coastline of the mainland. The in situ measurements indicated a later initiation of the breeze development, which is also observed in the model (at around 11:00 LT, Fig. 10a). Around noon, the sea breeze is enhanced at the coast, with higher wind speeds southward and northward of the valley. Still, the SB $(\sim 400 \mathrm{~m})$ is lower than the nearby hilly tops $(\sim 600 \mathrm{~m})$, and the air is constrained to enter into the valley where it is accelerated (not shown). In the afternoon, reaching maximum of $8 \mathrm{~m} \mathrm{~s}^{-1}$ at $140 \mathrm{~m}$, the 800 -m deep SB penetrates as far as $40 \mathrm{~km}$ inland and then diverges (Fig. 10b). The offshore SB extent ( $75 \mathrm{~km}$ long) is mostly constricted by the steep mountainous coasts of the nearby peninsula and mainland within the sea channel. As a result, the SB cell here is highly asymmetric. After 17:00 LT (Fig. 10c), the zone of higher wind speeds remains locked in front of the valley, because the sea-land temperature difference decreases. The SB diminishes over the next few hours. The next day, the SB penetration is deeper $(\sim 65 \mathrm{~km})$ but less intense over the valley due to an overlap with the large-scale wind flow (Fig. 7), which is in agreement with, for example, the 2-D results of Arritt (1993), with radar measurements for Florida (Atkins and Wakimoto, 1997) and with satellite measurements of the SB CZ over Spain (Azorin-Molina et al., 2009).

\subsubsection{Discussion of the daytime wind characteristics}

In general, both horizontal dimensions of the daytime breeze onshore and offshore varied significantly along the southeastern Adriatic coast. We observed two larger SB systems channelled by the river valleys and smaller circulations generated and modified by the numerous islands and sea channels. The estimation of the horizontal SB extent differs significantly for the onshore and offshore dimensions. While the onshore penetration was visible by the breeze front position, the offshore penetration was rather obscured due to a prevailing synoptic wind over the Adriatic. Still, we estimated (on 24 April 2006) the offshore SB dimensions of two larger cells over the Krka Valley and over the Neretva Valley where offshore extents were almost doubled comparing to its onshore counterpart, about $100 \mathrm{~km}$ and $75 \mathrm{~km}$, respectively (first row, Table 2). This relatively large offshore SB extent was also observed by Klaić et al. (2009). The offshore dimensions of the smaller SB systems (e.g., over the island) were highly limited by the topography and the interaction with the other systems. The blocking effect of mountains can occur if the Burger number ( $B=h_{\mathrm{m}} N / f L_{\perp}$ ) is higher than 1 (Cui et al., 1998; Kottmeier, 2000; Prtenjak et al., 2006) depending only on $h_{\mathrm{m}}$, the mountain's halfwidth $\left(L_{\perp}\right), N$ and the Coriolis parameter $(f)$. For $h_{\mathrm{m}}$ and $L_{\perp}$, we substituted $1500 \mathrm{~m}$ and $50 \mathrm{~km}$ as the average vertical and horizontal spreading of the coastal mountainous belt, respectively. Above the island of Brač, we used $h_{\mathrm{m}}=778 \mathrm{~m}$ and $L_{\perp}=5 \mathrm{~km}$. For the $44^{\circ} \mathrm{N}$ latitude and the spatially various $N$, the resulting Burger numbers vary from 2.8 to 11.5 . This means that the blocking of the steep coastal terrain is significant and, therefore, the inland penetration above the mainland is slowed down.

One possible approach in determining the SB proportions is to compare the spatial SB dimensions (modelled here) with the estimated theoretical vertical $\left(z_{\mathrm{sb}}\right)$ and horizontal $\left(x_{\mathrm{sb}}\right)$ 


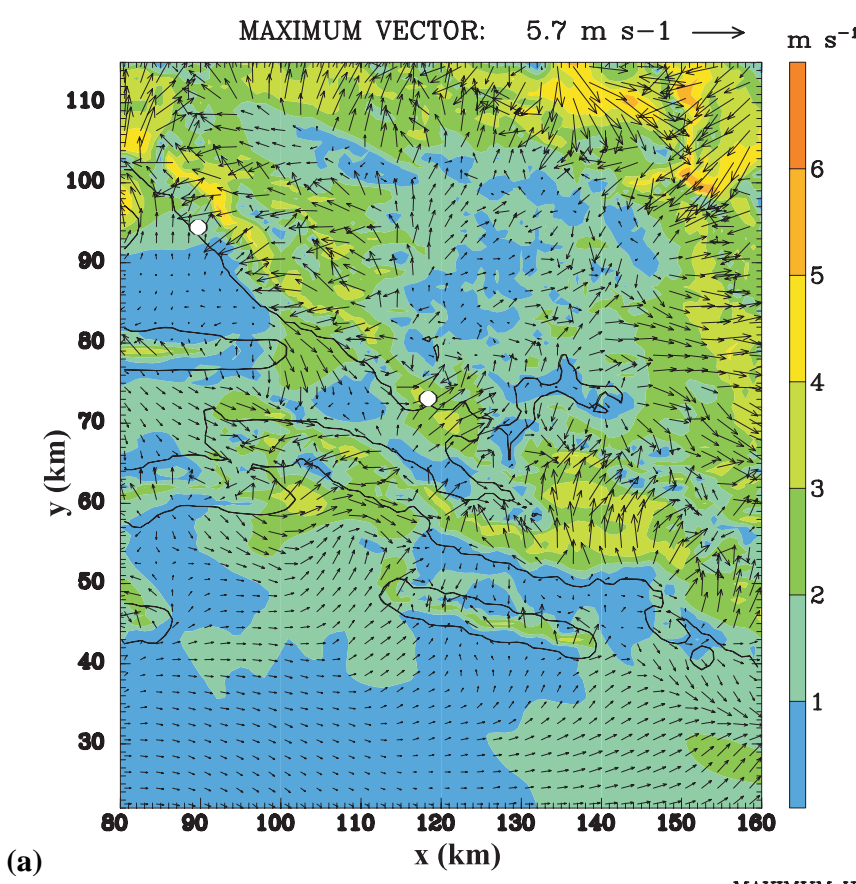

(a)
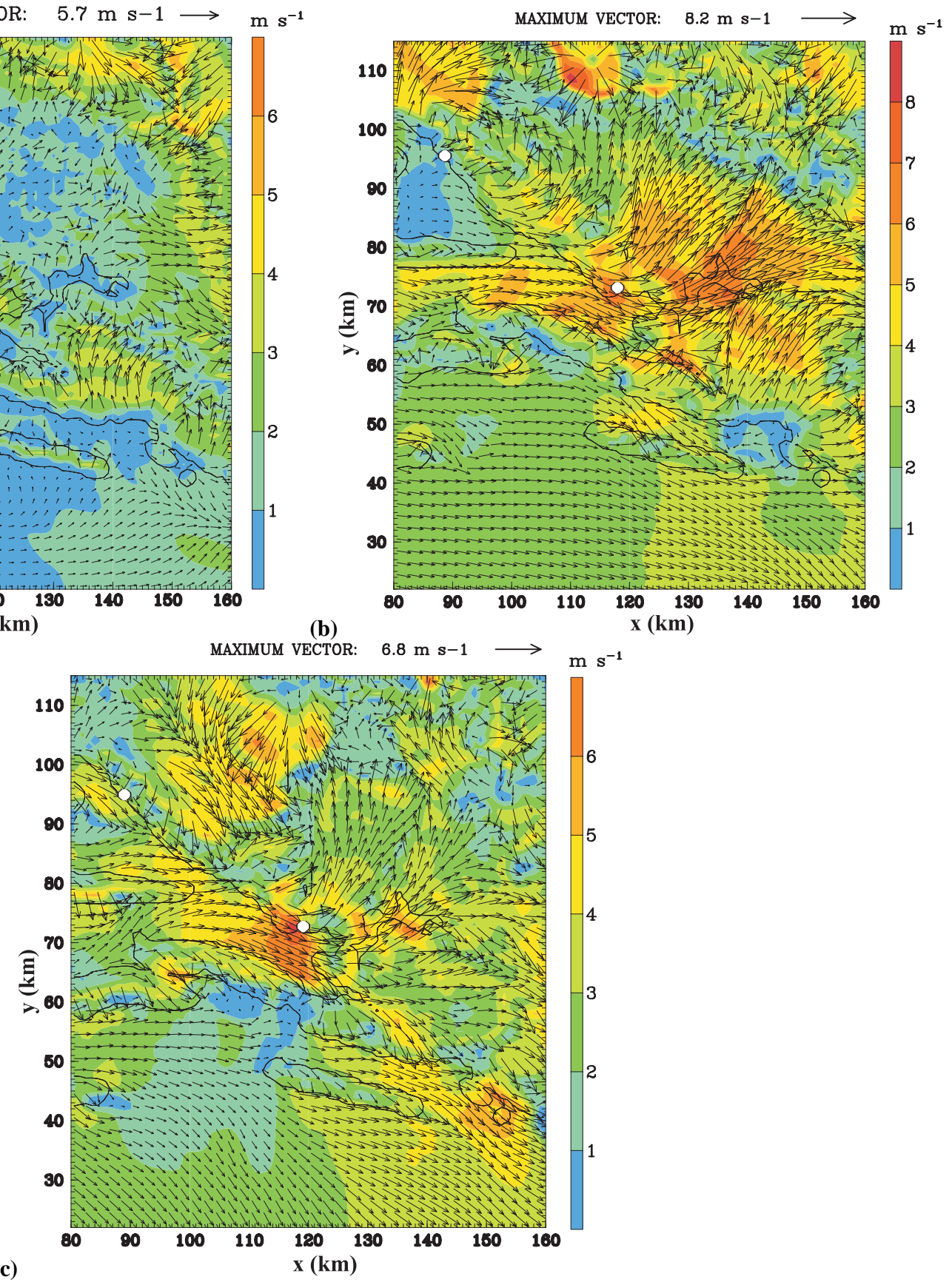

Fig. 10. A close-up of the near-surface flow within frame B in Fig. 7b on 24 April 2006, at (a) 11:00 LT, (b) 14:00 LT and (c) 17:00 LT, respectively. The wind speed is depicted by filled areas (legend on the right) with a $1 \mathrm{~m} \mathrm{~s}^{-1}$ interval. White circles denote measuring sites (see also Table 1).

extent of the SB, as well as the mean SB wind speed $\left(u_{\mathrm{sb}}\right)$, as proposed by Steyn $(1998,2003)$. Steyn showed that the SB depth was directly related to the surface layer's turbulent sensible heat $(H)$, and inversely related to the stability of the atmosphere through $N$ and the air-sea temperature difference $(\Delta T)$ (see Eq. 3 in Steyn, 2003). While the horizontal dimension is proportional to the ratio $N H /(\Delta T)$ (Steyn, 1998), the mean SB speed is predominantly driven by $H$, and it is independent of $N$ and $\Delta T$ (see Eq. 4 in Steyn, 2003). Using this scaling analysis, we found that the predicted mean SB speed varied spatially from 2.8 to $4.1 \mathrm{~m} \mathrm{~s}^{-1}$, as did the average SB depth (from $\sim 700$ to $1000 \mathrm{~m}$; Table 2). The theoretical $z_{\mathrm{sb}}$ are somewhat higher, and the calculated $x_{\mathrm{sb}}$ are lower than the dimensions directly taken from the modelled wind field. 
Table 2. Some calculated parameters of the sea breeze characteristics for 24 April 2006 at 14:00 LT. The first two columns correspond to the ratio between offshore $\left(L_{\text {offshore }}\right)$ and onshore $\left(L_{\text {onshore }}\right)$ extent and the nondimensional Burger number obtained as the ratio of mountain height $\left(h_{\mathrm{m}}\right)$, Brunt-Väisälä frequency $(N)$, mountain halfwidth $\left(L_{\perp}\right)$ and Coriolis parameter $(f)$. The mean sea breeze intensity $\left(u_{\mathrm{sb}}\right)$ is also estimated by scaling laws (Eq. 4 in Steyn, 2003), estimated average sea breeze depth $\left(z_{\mathrm{sb}}\right)$ (Eq. 3 in Steyn, 2003) and a theoretical sea-breeze ratio $x_{\mathrm{sb}} / z_{\mathrm{sb}}=N / \omega$, as in Steyn (1998), where $\omega$ is the diurnal frequency $\left(=2 \pi\right.$ day $\left.^{-1}\right)$. The horizontal sea breeze extent $\left(x_{\mathrm{sb}}\right)$ is defined as $z_{\mathrm{sb}} N / \omega$ (Drobinski et al., 2006).

\begin{tabular}{lccccccc}
\hline & $L_{\text {offshore }} / L_{\text {onshore }}$ & $B=h_{\mathrm{m}} N / f L_{\perp}$ & $u_{\mathrm{sb}}\left(\mathrm{m} \mathrm{s}^{-1}\right)$ & $z_{\mathrm{sb}}(\mathrm{m})$ & $z_{\mathrm{sb}} / u_{\mathrm{sb}}$ & $x_{\mathrm{sb}} / z_{\mathrm{sb}}=N / \omega$ & $x_{\mathrm{sb}}=(\mathrm{km})$ \\
\hline Krka Valley & 2 & 2.8 & 3.3 & 951 & 288 & 127 & 121 \\
Split airport & & 3.2 & 4.1 & 1044 & 251 & 114 & 105 \\
Brač airport & & 11.5 & 3.4 & 992 & 292 & 130 & 97 \\
Neretva Valley & 1.8 & 3.8 & 2.8 & 749 & 274 & 130 \\
\hline
\end{tabular}

The main deviation is visible in underestimated average $u_{\mathrm{sb}}$ within the Neretva Valley, where the scaling laws depreciate horizontal spreading of the asymmetric channelled SB. Nevertheless, a certain correspondence exists, and the scaling analysis seems to give acceptable results.

Here, we compare the estimated theoretical magnitudes with those obtained for similar events in temperate latitudes, such as SE France (Bastin et al., 2005; Drobinski et al., 2006). For example, the ratio $z_{\mathrm{sb}} / u_{\mathrm{sb}}$ is in the range of 251-292 (Table 2), and it is rather similar (although slightly higher) to those estimated for the Rhone valley, which is from 230 (measurements) to 250 (model) (Bastin et al., 2005). Another calculated ratio is the theoretical ratio $x_{\mathrm{sb}} / z_{\mathrm{sb}}$ (see Table 4 in Drobinski et al., 2006), which corresponds to the $N /\left(2 \pi\right.$ day $\left.^{-1}\right)$ according to Steyn (1998). For the Rhone valley $\left(43.5^{\circ} \mathrm{N}\right.$; Drobinski et al., 2006) the ratio is around 200, and about 138 for the Vancouver area $\left(49^{\circ} \mathrm{N}\right.$; Steyn, 1998). Here $\left(44^{\circ} \mathrm{N}\right)$, for four chosen mature SB circulation cells (14:00 LT), the ratio is in the range of 105 to 130 (Table 2). Because the vertical extent is not significantly different from that in France, the main difference is in the horizontal extent, especially in the smaller inland SB penetration.

As discussed by Drobinski et al. (2006), the wind speed is only reasonably predicted by the scaling laws in the pure SB case. The horizontal extent and the wind speed will be estimated less successfully if the synoptic-scale wind affects the SB system. In contrast to Drobinski et al. (2006), who obtained an overestimation of the real $x_{\mathrm{sb}}$ (especially during $\mathrm{SB} /$ mistral interaction), we obtained an underprediction of the same parameter. The scaling analysis was mostly performed on relatively flat terrain (Canada, Spain and Netherlands) in wide valleys and, therefore, there can be some deviations in its application to the complex, indented and mostly steep terrain in this study.

\subsection{Modelled nighttime wind field characteristics}

On 24 April 2006, the nighttime breeze is established (Fig. 11) between 19:00 LT and 22:00 LT. The offshore breeze (a superposition of the LB and downslope wind) oc- curs along the coast and over the southern (steep) slopes of most of the islands in the model domain, reaching maximum speeds $\left(3.4 \mathrm{~m} \mathrm{~s}^{-1}\right)$ in the most SE part of the main coast. Not surprisingly, the model reproduced weaker nighttime breezes (by at least a factor of 2) compared to its daytime counterpart, which can also be seen in the measurements. This result also agrees with former studies (e.g., Orlić et al., 1988; Klaić et al., 2009) and with the climatology (Fig. 2). Over the tops of the islands the divergence in the wind structure dominates.

The multiform near-surface wind field at 21:00 LT reveals nocturnal smaller-scale formations. Through the mountain gaps near the island of Brač, the nighttime flow is significantly channelled. The north-westerly land breeze develops over the convex part of the coast northward of the Split airport. Under large-scale wind assistance, this NW wind forms one of the most prominent features, the whirling about the island near the Split airport. This small mesoscale vortex (within the lowermost $300 \mathrm{~m}$ ) is implied by the surface (Fig. 11a) and by the sodar measurements (Fig. 12). Together with the offshore breeze over the mainland, it creates a relatively shallow and weak nocturnal CZ near the Split airport, with a maximum soon after midnight (maximum updraft up to $0.5 \mathrm{~m} \mathrm{~s}^{-1}$, Fig. 11b). According to the strength of the LB, the spatial dimensions of the cyclonic vortex vary in time. This cyclonic eddy was also observed the night before (not shown). Southward, the dominant north-westerly wind is also constrained into the sea channels between the islands. It collides with the offshore thermally induced flows, resulting in the formation of another (now) nighttime $\mathrm{CZ}$ near the island of the Brač airport. However, this $\mathrm{CZ}$ is also relatively weak and shallow, reaching its maximum around 23:00 LT.

\section{Summary and conclusions}

Here we investigated the main characteristics of the shallow sea/land breeze in the highly complex topography of the south-eastern Adriatic. The investigation was performed for one chosen period, 24-25 April 2006. This period was characterised by weak synoptic-scale winds and a negligible 
(a)

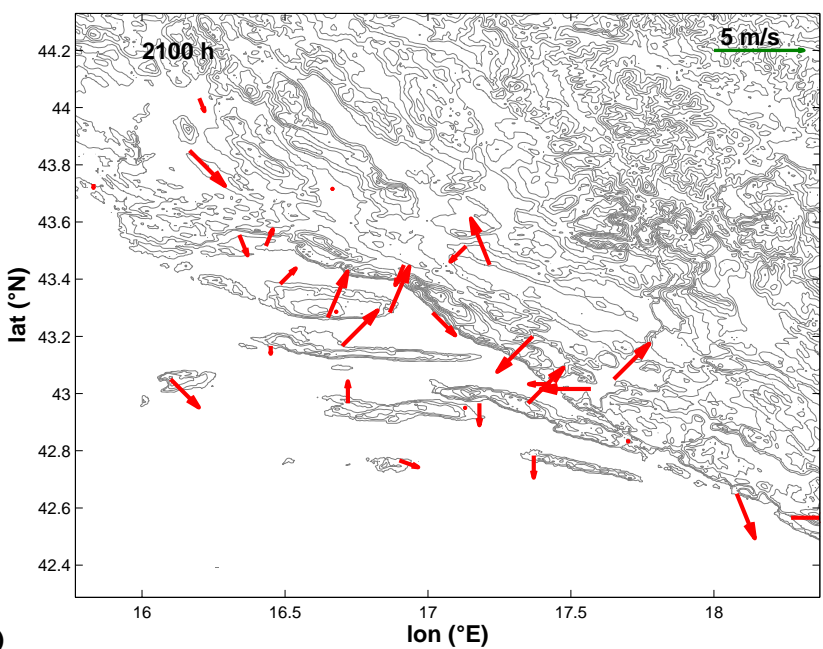

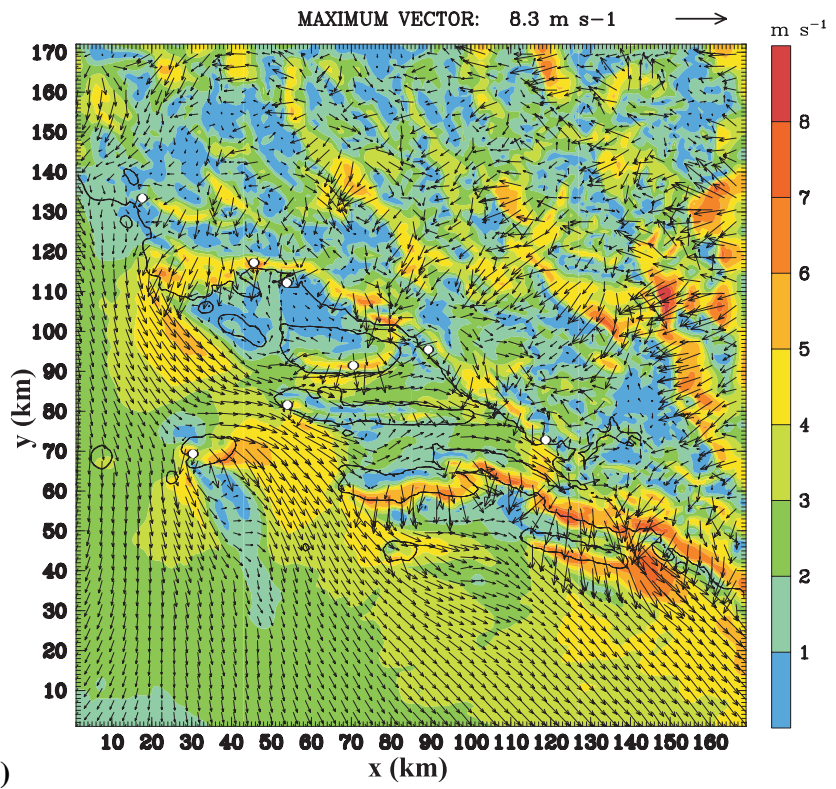

Fig. 11. Same as in Fig. 7a, b except for the modelled 10-m wind $\left(\mathrm{m} \mathrm{s}^{-1}\right)$ on 24 April 2006 at 21:00 LT.

influence of the Etesian winds. Apart from the radiosoundings and QuikSCAT data, we also used in situ data from the operational meteorological surface sites, sodar data and a model with fine grid spacing. The near-surface measurements compared to the climatology showed that 24 April 2006 represented an almost "typical" SB day for the area, while 25 April 2006 allowed a comparison among SB systems during opposite synoptic-scale winds. Both large-scale winds, the prevailing north-westerly on 24 April 2006 and the south-easterly on 25 April 2006, were generally parallel to the Adriatic coast.

In general, the complex topography is the main source of perturbation of the shallow breeze features. We observed several separate, thermally forced flows with different intensities and spatial dimensions, which did not develop simultaneously. The SB systems were established with wind speeds increasing in time on the coasts and over the slopes, usually interacting with the upslope winds that also developed there. The landward flow had the intensity in range of $3.5-5 \mathrm{~m} \mathrm{~s}^{-1}$ and a prevailing south-western direction with the lifetime of approximately 8 (or less) hours. The passes between the coastal mountain peaks modified the inflow penetration, provoking an increase of wind speeds in the channelled flow. As a second consequence of this modification, the significantly curved coastline caused the formation of the numerous irregular convergence zones, which were characterised by the enhanced horizontal shear zones and intense updrafts. The same phenomena were observed over the central parts of nearby large islands, where the air impinging occurred due to the advection of local flows from different coasts. Apart from the acceleration of low-level wind, the sea channels participated in the formation of small eddies in the near-surface flow over a 24-h period. The distant islands were mostly under the influence of the discernible synopticscale flow.

In contrast to the influence of the complex topography in south-eastern France, where the large valleys decreased SB intensity and increased its inland penetration (Bastin and Drobinski, 2006), the complex topography in our study area significantly retarded inland penetration (Burger numbers always $>1$, Table 2), pushing the SB systems more seaward. Therefore, in the large(r) SB systems, the offshore horizontal dimension was almost twice as large as the onshore component. This type of coastal flow, affected by an exceptionally steep coastal terrain, corresponds to the topographic flow observed in the Baltic region (Cui et al., 1998), in south-eastern Spain (Kottmeier, 2000) and in north-eastern Adriatic (Prtenjak et al., 2006).

We isolated several prominent, region-specific airflow features, thus, filling the gaps in our knowledge of the sea/land breeze characteristics along the south-eastern Adriatic. These are as follows:

- An acceleration of the SB occurred in the sea channels and through the mountainous gaps. However, the strongest SB channelling was observed above the valley of the Neretva River, where the SB reached $40 \mathrm{~km}$ inland with a strength of $8 \mathrm{~m} \mathrm{~s}^{-1}$. A highly asymmetric offshore part was constricted within the sea channel in front of the valley.

- The CZ near the Split airport. In the afternoon, the CZ extended up to $1.1 \mathrm{~km}$ with intense updrafts $\left(>1 \mathrm{~m} \mathrm{~s}^{-1}\right)$ as a result of merged SB heads of westerly and southeasterly breeze flows. During its westward movement, 
the daytime $\mathrm{CZ}$ approached $4 \mathrm{~km}$ from the airport. Although the SB decayed in the area, another nighttime $\mathrm{CZ}$ zone occurred. This $\mathrm{CZ}$ zone was weaker and shallower than the daytime one, being placed in front of the Split airport over the sea, due to the wind convergence of the north-westerly LB and a substantial swirling around the nearby island.

- Due to the impinging of the airflow above the central part of island, the produced $\mathrm{CZ}$ over the island of Brač was highly influenced by the terrain. Significantly curved in space from the relatively low NW part of island towards the eastern lowest part, the well-developed $\mathrm{CZ}$ was associated with strong updrafts $\left(>1 \mathrm{~m} \mathrm{~s}^{-1}\right)$ $2 \mathrm{~km}$ from the airport. During the night, the weak CZ continued to exist, now due to the interaction of the synoptic-scale north-westerly wind constrained by the sea channel and the offshore local wind.

In general, the distance between the CZs and the airports depends on the large-scale wind direction. The above results suggest that the smallest distance (and presumably the largest impact) prefers the north-westerly synoptic-wind. Because the Etesians represent this kind of large-scale wind, the occurrence of CZs near the airports is presumably very high during the summer and, therefore, they should be considered a potential risk to the aircraft traffic (especially to light aircrafts and/or gliders) in the wider airport area. Knowledge of the nearby $\mathrm{CZ}$ formation can surely improve everyday aircraft forecasts.

Finally, considering limitations of the model prediction as well as limitations of the used available measurements (e.g., uncertainties in QuikSCAT data and nighttime sodar measurements), we believe that the conclusions are generally appropriate for the SB small-scale investigations in the south-eastern Adriatic region. Phenomena like eddies and CZs need to be better supported by additional measurements, which hopefully will allow for further research in the area and the implementation of a small-scale investigation.

Acknowledgements. This work has been supported by the Ministry of Science, Education and Sports (BORA grant No. 119-11930861311, No. 037-1193086-2771, Dept. of Mathematics, No. 0980982705-2707, IRB). The authors are indebted to the Meteorological and Hydrological Service of the Republic of Croatia and the Meteorological Department of the Croatian Air Traffic Control at Zagreb Airport for providing the meteorological data.

Topical Editor P. M. Ruti thanks two anonymous referees for their help in evaluating this paper.

\section{References}

Arritt, R. W.: Effects of the large-scale flow on characteristic features of the sea breeze, J. Appl. Meteorol., 32, 116-125, 1993.

Atkins, N. T. and Wakimoto, R. M.: Influence of the synoptic-scale flow on sea breezes observed during CaPE, Mon. Weather Rev., 125, 2112-2130, 1997.
Azorin-Molina, C., Connell, B. H., and Baena-Calatrava, R.: Sea-Breeze Convergence Zones from AVHRR over the Iberian Mediterranean Area and the Isle of Mallorca, Spain, J. Appl. Meteorol. Climatol., 48, 2069-2085, doi:10.1175/2009JAMC2141.1, 2009.

Baklanov, A. and Grisogono, B. (Eds): Atmospheric Boundary Layers: Nature, Theory and Applications to Environmental Modelling and Security, Springer, New York, 241 pp., 2007.

Banta, R. M., Olivier, L. D., and Levinson, D. H.: Evolution of the Monterey Bay sea breeze layer as observed by pulsed Doppler lidar, J. Atmos. Sci., 50, 3959-3982, 1993.

Banta, R. M.: Sea breezes shallow, and deep on the California coast, Mon. Weather Rev., 123, 3614-3622, 1995.

Bastin, S., Drobinski, P., Dabas, A. M., Delville, P., Reitebuch, O., and Werner, C.: Impact of the Rhône, and Durance valleys on sea breeze circulation in the Marseille area, Atmos. Res., 74, 303 328, 2005.

Bastin, S. and Drobinski, P.: Sea-breeze-induced mass transport over complex terrain in south-eastern France: A case study, Q. J. Roy. Meteorol. Soc., 132, 405-423, 2006.

Caballero, R. and Lavagnini, A.: A numerical investigation of the sea breeze and slope flows around Rome, Il Nuovo Cimento, 25 , 287-304, 2002.

Cui, Z., Tjernstrom, M., and Grisogono, B.: Idealized simulations of atmospheric coastal flow along the central coast of California, J. Appl. Meteorol., 37, 1332-1363, 1998.

Drobinski, P., Bastin, S., Dabas, A., Delville, P., and Reitebuch, O.: Variability of three-dimensional sea breeze structure in southern France: observations and evaluation of empirical scaling laws, Ann. Geophys., 24, 1783-1799, doi:10.5194/angeo-241783-2006, 2006.

Epifanio, C. C. and Durran, D. R.: Lee-vortex formation in free-slip stratified flow over ridges. Part I: Comparison of weakly nonlinear inviscid theory and fully nonlinear viscous simulations, J. Atmos. Sci., 59, 1153-1165, 2002.

Federico, S., Dalu, G. A., Bellecci, C., and Colacino, M.: Mesoscale energetics and flows induced by sea-land and mountain-valley contrasts, Ann. Geophys., 18, 235-246, doi:10.1007/s00585-000-0235-3, 2000.

Fortezza, F., Strocchi, V., Giovanelli, G., Bonasoni, P., and Georgiadis, T.: Transport of photochemical oxidants along the Northwestern Adriatic Coast, Atmos. Environ., 27, 2393-2402, 1993.

Haurwitz, B.: Comments on the sea-breeze circulation, J. Meteorol., 4, 1-8, 1947.

Heimann, D.: A model-based wind climatology of the eastern Adriatic coast, Meteorol. Z., 10, 5-16, 2001.

Jimenez-Guerrero, P., Jorba, O., Baidasanoa, J. M., and Gasso, S.: The use of a modelling system as a tool for air quality management: Annual high-resolution simulations and evaluation, Science Total Environ., 390, 323-340, 2008.

Kain, J. S., Weiss, S. J., Levit, J. J., Baldwin, M. E., and Bright, D. R.: Examination of convection-allowing configurations of the WRF model for the prediction of severe convective weather: The SPC/NSSL Spring Program 2004, Weather Forecast., 21, 167181,2006

Klaić, Z. B., Pasarić, Z., and Tudor, M.: On the interplay between sea-land breezes and etesian winds over the central Adriatic, J. Marine Syst., 78, S101-S118, doi:10.1016/j.jmarsys.2009.01.016, 2009. 
Kottmeier, C., Palacio-Sese, P., Kalthoff, N., Corsmeier, U., and Fiedler, F.: Sea breezes and coastal jets in southeastern Spain, Int. J. Climatol., 20, 1791-1808, 2000.

Lukšić, I.: Sea and land breezes at Goveðari on the island of Mljet, Hrv. Meteor. časopis, 30, 39-53, 1995 (in Croatian).

Lukšić, I.: Some relations between sea breeze, etesians and atmospheric disturbance, Hrv. Meteor. časopis, 39, 121-133, 2004 (in Croatian).

Makjanić, B.: Sea/land breezes: contribution to the mathematical theory and sea/land breeze analysis along Adriatic coast, $\mathrm{PhD}$ thesis, Faculty of Science, University of Zagreb, Croatia, 146 pp., 1958.

Mangia, C., Schipa, I., Tanzarella, A., Conte, D., Marra, G. P., Miglietta, M. M., and Rizza, U.: A numerical study of the effect of sea breeze circulation on photochemical pollution over a highly industrialized peninsula, Meteorol. Appl., 17, 19-31, 2010.

Mastura, M.: Mesoscale equatorial wind prediction in Southeast Asia during a haze episode of 2005, Geofizika, 26, 67-84, 2009.

McPherson, R. D.: A numerical study of the effect of coastal irregularity on the sea breeze, J. Appl. Meteor., 9, 767-777, 1970.

Melas, D., Lavagnini, A., and Sempreviva, A.-M.: An investigation of the boundary layer dynamics of Sardinia island under sea-breeze conditions, J. Appl. Meteor., 39, 516-524, 2000.

Miao, J.-F., Wyser, K., Chen, D., and Ritchie, H.: Impacts of boundary layer turbulence and land surface process parameterizations on simulated sea breeze characteristics, Ann. Geophys., 27, 2303-2320, doi:10.5194/angeo-27-2303-2009, 2009.

Michalakes, J., Dudhia, J., Gill, D., Henderson, T., Klemp, J., Skamarock, W., and Wang, W.: The Weather Research and Forecasting Model: software architecture and performance, in: 11th ECMWF Workshop on the use of High Performance Computing in Meteorology, edited by: Mozdzynski, G., Reading, UK, 2004.

Miller, S. T. K., Keim, B. D., Talbot, R. W., and Mao, H.: Sea breeze: Structure, forecasting, and impacts, Rev. Geophys., 41(3), 1011, doi:10.1029/2003RG000124, 2003.

Nitis, T., Kitsiou, D., Klaić, Z. B., Prtenjak, M. T., and Moussiopoulos, N.: The effects of basic flow and topography on the development of the sea breeze over a complex coastal environment, Q. J. Roy. Meteorol. Soc., 131, 305-328, 2005.

Orlić, M., Penzar, B., and Penzar, I.: Adriatic sea and land breezes: Clockwise versus anticlockwise rotation, J. Appl. Meteor., 27, 675-679, 1988.

Pandžić, K. and Likso, T.: Eastern Adriatic typical wind field patterns and large-scale atmospheric conditions, Int. J. Climatol., 25, 81-98, 2005.

Penzar, B., Penzar, I., and Orlić, M.: Weather and climate of the east Adriatic (in Croatian). Nakladna kuća Dr.Feletar, Zagreb, Croatia, 258 pp., 2001.
Prtenjak, M. T., Grisogono, B., and Nitis, T.: Shallow mesoscale flows at the north-eastern Adriatic coast, Q. J. Roy. Meteorol. Soc., 132, 2191-2216, 2006.

Prtenjak, M. T. and Grisogono, B.: Sea/land breezes climatological characteristics along the northeastern Adriatic coast, Theoret. Appl. Climatol., 90, 201-215, doi:10.1007/s00704-006-0286-9, 2007.

Prtenjak, M. T., Pasarić, Z., Orlić, M., and Grisogono, B.: Rotation of sea/land breezes along the northeastern Adriatic coast, Ann. Geophys., 26, 1711-1724, doi:10.5194/angeo-26-17112008, 2008.

Prtenjak, M. T., Jeričević, A., Nitis, T., Alebić-Juretić, A., and Klaić, Z. B.: Atmospheric boundary layer characteristics during high ozone concentrations in the Rijeka Bay area, in: Proceedings of the Second International Conference on Environmental Management, Engineering, Planning and Economics (CEMEPE 09) \& SECOTOX Conference, Mykonos, Greece, 21-26 June 2009, 1177-1182, 2009.

Sakazaki, T. and Fujiwara, M.: Diurnal Variations in Summertime Surface Wind upon Japanese Plains: Hodograph Rotation and Its Dynamics, J. Meteorol. Soc. Jap., 86, 787-803, 2008.

Simpson, J. E.: Sea breeze, and local winds, Cambridge University Press, UK, 234 pp., 1994.

Skamarock, W. C. and Klemp, J. B.: A time-split nonhydrostatic atmospheric model for weather research and forecasting applications, J. Comput. Phys., 227, 3465-3485, 2008.

Skamarock, W. C., Klemp, J. B., Dudhia, J., Gill, D. O., Barker, D. M., Wang, W., and Powers, J. G.: A description of the Advanced Research WRF Version 2, NCAR/TN-468+STR, NCAR TECHNICAL NOTE, 88 pp., online available at: http://wrf-model.org/ wrfadmin/docs/arw_v2.pdf, 2005.

Smith, R. B. and Grubišić, V.: Aerial observations of Hawaii's wake, J. Atmos. Sci., 50, 3728-3750, 1993.

Steyn, D. G.: Scaling the vertical structure of sea breezes, Bound.Lay. Meteorol., 86, 505-524, 1998.

Steyn, D. G.: Scaling the vertical structure of sea breezes revisited, Bound.-Lay. Meteorol., 107, 177-188, 2003.

Tang, W., Liu, W. T., and Stiles, B. W.: Evaluation of High-Resolution Ocean Surface Vector Winds Measured by QuikSCAT Scatterometer in Coastal Regions, IEEE Transactions on Geoscience and Remote Sensing 2004, 42(8), 1762-1769, 2004.

Trošić, T., Šinik, N., and Trošić, Ž.: Available potential energy of the daily coastal circulation at Zadar (Croatia), Meteorol. Atmos. Phys., 93, 2110-2220, doi:10.1007/s00703-005-0179-y, 2006.

Willmott, C. J.: Some comments on the evaluation of model performance, B. Am. Meteorol. Soc., 63, 1309-1313, 1982. 